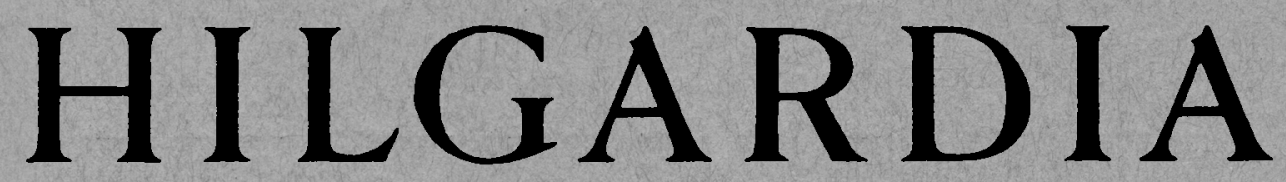

A Journal of Agricultural Science Published by the California Agricultural Experiment Station

\title{
DETERMINING WATER NEEDS FOR CROPS FROM CLIMATIC DATA
}

\author{
N. A. HALKIAS, F. J. VEIHMEYER, \\ and A. H. HENDRICKSON
}


The best measure of water use by crops is found by soil sampling to obtain the changes in soil moisture. Reproducible results are obtained by this method, if there is a long, rainless period during the growing season, and if the irrigations are far enough apart so that at least three samplings may be obtained between waterings.

The difference in evaporation between black and white atmometers has shown a high correlation with the use of water by crops and also with the solar radiation as measured by an Eppley pyrheliometer.

Loss of water from a given area is associated with the energy received from the sun, and the ground coverage of the plants as long as the soil moisture is above the permanent wilting percentage.

Rates of use of water by crops may vary from year to year, but if the ground coverage is equal, the use is the same in any given year in spite of the size of the individual plants. Large differences in loss of water by crops may occur if the coverage of the ground by the plants differs.

The correlation between evaporation from a white atmometer and from a standard United States Weather Bureau pan suggests that the former could be substituted for the latter for measurement of evaporation. 


\section{$\begin{array}{llllllll}H & \text { I } & \text { L } & G & A & R & D & \text { I A }\end{array}$}

A Journal of Agricultural Science Published by

the California Agricultural Experiment Station

\begin{tabular}{lcc}
\hline VoL. 24 & DECEMBER, 1955 & No. 9 \\
\hline
\end{tabular}

\section{DETERMINING WATER NEEDS FOR CROPS FROM CLIMATIC DATA ${ }^{1}$}

\section{N. A. HALKIAS, ${ }^{2}$ F. J. VEIHMEYER, ${ }^{3}$ and A. H. HENDRICKSON ${ }^{4}$}

\section{INTRODUCTION}

DETERMINING WATER requirements for various crops is of great importance, particularly in arid and semiarid regions. With water often the limiting factor in the expansion of agriculture, information concerning water requirements for crops is necessary in designing irrigation systems and in planning irrigation programs.

Irrigationists frequently are called upon to make estimates of present or future water needs for certain localities. Often, however, they are not allowed enough time to make direct measurements of the use of water.

Much effort has been spent in attempting to correlate certain climatic factors with use of water by plants, and a number of formulas have been suggested for the indirect measurement of water consumption. This report gives the results of studies on the correlation of some climatic measurements and the use of water by crops. The latter data were obtained by measuring the extraction of water from the soil by plant transpiration and evaporation directly from the surface of the soil.

\section{FACTORS AFFECTING TRANSPIRATION AND EVAPORATION}

Transpiration is like evaporation from wet surfaces but, unlike evaporation, it may be controlled to a certain extent by conditions within the plant.

External Factors. The important external factors influencing transpiration are sunlight, temperature, humidity, wind, and soil moisture when the latter has been reduced to the condition known as the permanent wilting percentage. The amount and quality of the sunlight probably exert more influence than the other factors. In arid climates, high temperatures are

${ }^{1}$ Received for publication February 25, 1955.

${ }^{2}$ Dr. Halkias is a member of the staff of the Ministry of Agriculture, Greece. He did special research in the Department of Irrigation, University of California at Davis, during 1953-55.

${ }^{3}$ Professor of Irrigation, Emeritus, Experiment Station, Davis.

${ }^{4}$ Pomologist in the Experiment Station, Davis. 
usually accompanied by low humidities, which tend to increase transpiration. Transpiration may be less on a calm day than on a windy one, but it does not increase in direct proportion to wind velocity.

Morphological Factors. The morphological features of the plant, such as type of epidermis, kind, distribution, size, and opening of the stomata, can have some influence on transpiration. It is doubtful, however, whether the plant has much control over its loss of water. The opening of the stomata is controlled by external conditions surrounding the plant which, in turn, may affect the kind and concentration of solutes in the guard cells. The regulatory effect of the stomata on transpiration may be very slight. Their opening or closing may take place after changes in transpiration-because of environmental variations-have occurred.

There is not much difference in the rate of transpiration from equal areas of leaves of different common crop plants when exposed under similar climatic conditions. There may be a large difference, however, in loss of water from areas planted to different crops because of relative coverage of the ground by the plants.

Veihmeyer $(1927,1938,1953)^{5}$ and Veihmeyer and Brooks (1954) show that in regions of rainless summers loss of water by direct evaporation of water from the soil surface is a very small part of the total amount taken out of the soil by plant transpiration. If a large portion of a field is covered by plants, greater losses of moisture will occur than if a lesser amount of the ground is covered.

If transpiration is a function of soil moisture the latter should be included as a variable in any equation which is suggested to show the relation of water use and climate. The equations derived for these relationships, however, usually are based upon the assumption that the plants were adequately supplied with water. Therefore, soil moisture as one of the variables is not included.

Usually the moisture content of the soil on which actively transpiring plants are growing in the field is constantly changing. If such changes do affect transpiration they should be considered carefully.

Responses of plants to soil moisture conditions are generally well known in irrigated regions. Among these are the vigorous growth of plants that are given sufficient water, the various symptoms shown by different plants when subjected to dry soil conditions, and the recovery and resumption of growth when water is supplied to the soil following a dry spell.

Factors Limiting Transpiration. Soil moisture, of course, becomes a limiting condition for transpiration and plant growth when it is reduced to the permanent wilting percentage. The question of whether transpiration decreases as soil moisture decreases has received much attention. Veihmeyer and Hendrickson (1950) reviewed investigations on this subject. They concluded, from their own studies extending over many years and from the work of others, that transpiration is independent of soil moisture so long as the moisture content of the soil in contact with the absorbing portion of the roots is at or above the permanent wilting percentage. Figures 1, 2, 9, and 10 give excellent examples of water readily available for transpiration even

\footnotetext{
${ }^{5}$ See "Literature Cited" for citations referred to in the text by author and date.
} 
though the soil moisture is allowed to drop to the permanent wilting percentage in an appreciable amount of the soil containing the roots. The details of these will be discussed later.

The question of whether transpiration is a function of soil moisture was recently submitted to a selected group of investigators in the field of plantsoil-water relations for discussion (Veihmeyer and Hendrickson, 1955). While differences of opinion exist, the best evidence shows that transpiration is independent of the level of soil moisture so long as it is above the permanent wilting percentage. Furthermore, the correlation of use of water (fig. 10) with certain climatic factors which are reported in this paper is found to hold irrespective of the soil moisture condition provided it is not allowed to reach the permanent wilting percentage and remains at this moisture level for an àppreciable time.

We are not concerned in this work with losses of water which may occur during its application but have confined our studies to the amount of water taken from the soil by plant transpiration and to that evaporated directly from the soil surface.

\section{METHODS DETERMINING LOSSES OF WATER FROM SOILS}

A number of methods for estimating the changes in soil moisture conditions have been suggested. The principal ones in use were discussed in a review by Veihmeyer and Hendrickson (1949). We believe there is no adequate method for measuring quantitatively the water in a field soil at a given time other than by taking soil samples and measuring their moisture content by weighing and oven-drying.

Weighing and Drying. In this work, therefore, samples were taken with a soil tube and dried at $110^{\circ} \mathrm{C}$ in an oven. The wet and dried weights then were used to calculate the moisture contents. The weight per unit volume of the soil in place in the field together with the soil moisture content give data from which the moisture percentages on the dry-weight basis can be converted to volumes. The acre-inches of water per acre (or simply inches taken from the soil in the intervals between sampling) are recorded.

This method of measuring the water taken from the soil by evaporation and transpiration requires the systematic collection of sufficient samples to give a true value for the average soil moisture condition in the field. The greater the variability in water-retaining properties of the soil in different parts of the field, the greater must be the number of samples.

Kinds of Root Systems. The soil must be deep enough to accommodate the root system of the plant to the full depth to which it normally would penetrate the soil. Some plants have poor root systems, because their roots do not thoroughly permeate the soil. Because portions of the soil are not occupied by roots, sampling either by a soil tube or by any other device will include some soil devoid of roots. In this case, the average moisture content of the samples will not give the true value for the soil which is in contact with the absorbing portion of the roots.

Some plants have a sparse root development only for the first part of their life cycle; later they develop good root systems. Others have poor root systems which persist throughout the entire season. Most permanently rooted 
crops, such as trees, have adequate root systems. Some annual plants, however, such as potatoes, corn, onions, and several varieties of beans, have sparse root systems (Doneen and Henderson, 1954).

Veihmeyer and Holland (1949) found that lettuce has a poor root system and that soil samples are not a good basis for determining the amount of water taken from the soil by this crop. It seems likely that a number of plants do not lend themselves to the kind of study reported herein; consequently, our studies were restricted to crops with well-developed root systems.

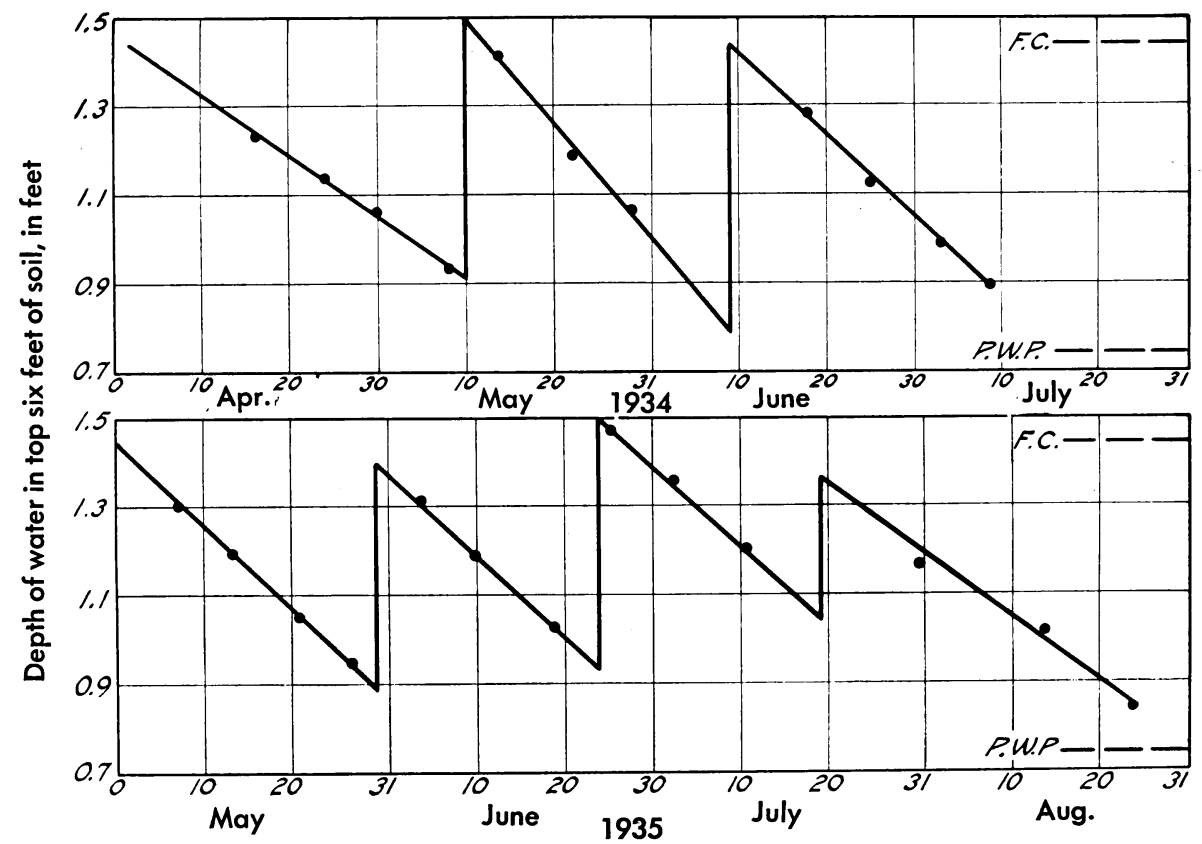

Fig. 1. Soil moisture extraction curves in a field cropped to sugar beets at Davis for the years 1934 and 1935. While the soil moisture fluctuated through a wide range, the plants were supplied with readily available moisture throughout the season. The field capacity and permanent wilting percentage of the soil are indicated.

Other prerequisites for this kind of investigation are soils of fairly uniform texture and structure, with the water table below the reach of the crop roots. With one exception, that of grapes in the Coachella Valley where the soil was laminated, these conditions were satisfied in our studies.

Soil conditions restricting the development of roots have been found (Veihmeyer and Hendrickson, 1948; Doneen and Henderson, 1952) where the soil is too dense to permit penetration of the roots. Lewis, Work, and Aldrich (1935) and Work and Lewis (1936) have reported a similar condition in a pear orchard in clay adobe soil.

Another precaution was to use data only from fields which were irrigated in a reasonable manner. It is obvious that evaporation losses from surface soil increase under very frequent water applications.

The relation between soil moisture and growth, as well as other plant responses, was reviewed by Veihmeyer and Hendrickson (1950). It was shown that the results of work which is susceptible to analysis lead to the 
conclusion that water needs of plants are satisfied if the moisture content of the soil in contact with the absorbing portion of the roots of the plants does not reach the permanent wilting percentage.

The intervals between irrigations in each instance were sufficient to allow the taking of several sets of samples. Usually the field was sampled at least three times between irrigations. Figures 1 and 2 are typical of the kind of

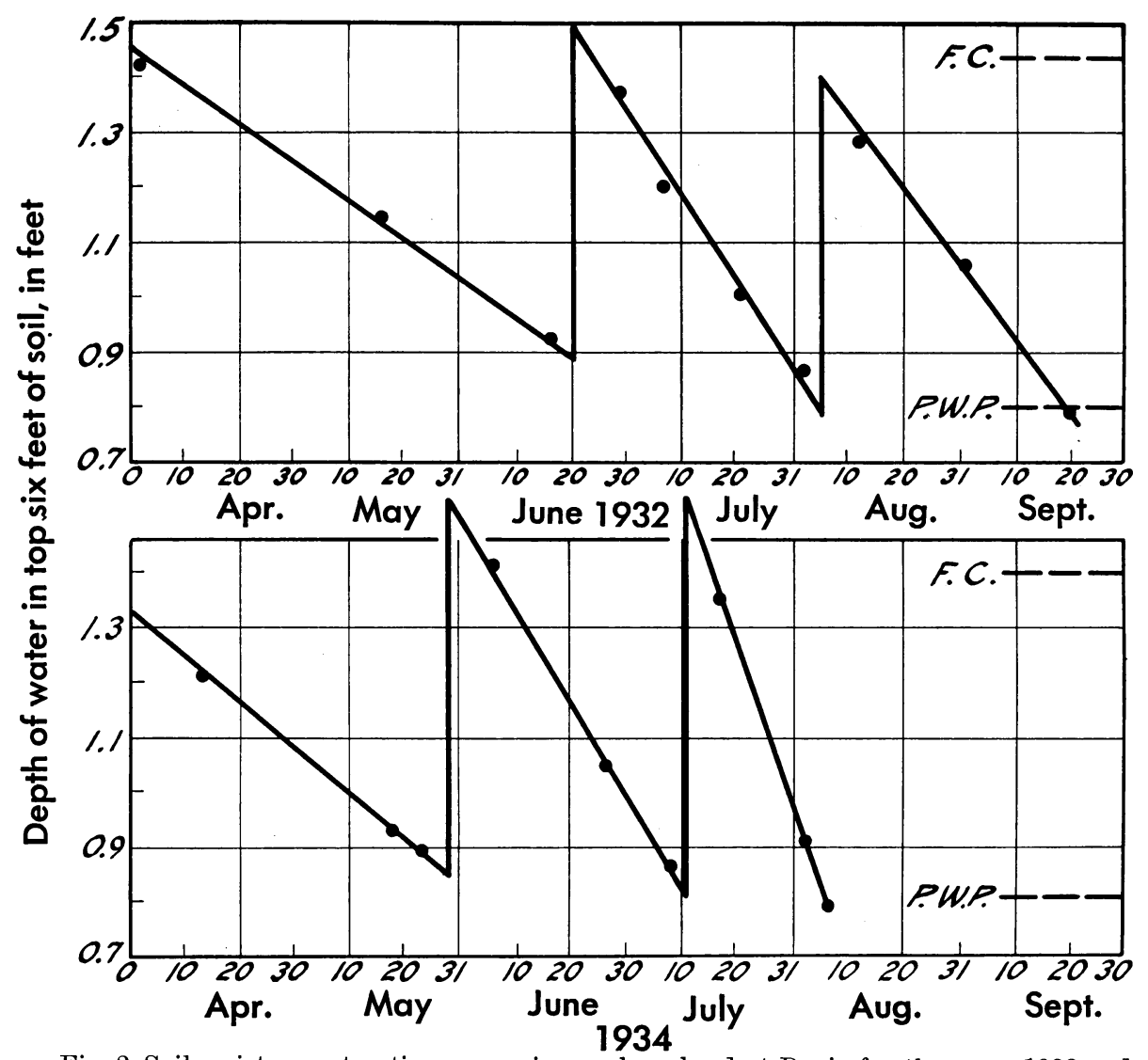

Fig. 2. Soil moisture extraction curves in peach orchard at Davis for the years 1932 and 1934. While the soil moisture fluctuated through a wide range, the plants were supplied with readily available moisture throughout the season. The field capacity and permanent wilting percentage of the soil are indicated.

data used to determine soil moisture extraction. It should be noted that these curves have uniform slopes indicating that use of water is independent of the level of soil moisture.

Container Experiments. The use of water by plants may be measured by growing them on soil in tanks or lysimeters and determining the water lost from the system. These measurements have not always been entirely satisfactory. Kittridge (1941) reported some of the difficulties encountered with such methods. It is not always possible to get satisfactory data when attempting to convert the loss of water from the containers to equivalent depths of water from field crops. The area of the exposed soil in the container may not 
be a reliable criterion for the conversion of the results to an acreage basis. Multiplying the data for a single plant by the number of plants in the field has not been successful. The area occupied by the plant receiving the incoming energy may be different from the area occupied by a similar plant in the field. Container experiments may, however, be used to obtain relative values or to measure certain soil moisture constants such as permanent wilting percentage.

Inflow-Outflow Measurements from Land Areas. Where the amount of water entering a known area of land is measured and the rainfall has been recorded, the difference between these and the amount flowing out of the area will be a measure of the losses by evaporation and transpiration. It is usually difficult to determine the total inflow and to be certain there is no subsurface flow past the points of measurement.

Integration Method. This method sums up the use for each crop, the use of natural vegetation, and the evaporation from bare land. The rate of water use for the different kinds of vegetation as well as evaporation from bare soils must be known in using this method.

These and other methods used to estimate water requirements were reviewed in considerable detail by Blaney, et al. (1952). We believe, however, that the most reliable method for determining water use is by soil-moisture studies.

\section{REVIEW OF LITERATURE IN THE FIELD}

Actual measurements of water use by crops are expensive and time-consuming; therefore, attempts were made to determine use of water from climatic data. Briggs and Shantz $(1916 a, 1916 b)$ showed a relation between transpiration, amount of evaporation from a free water surface, air temperature, solar radiation, and wet-bulb depression readings. Their studies, which were made with plants in containers, were for very short periods of time. Many formulas have been developed for determining evaporation from water surfaces from meteorological data but only a few methods have been suggested for determining water use by crops based on climatological data. Those which have been proposed for estimating evaporation are quite similar.

C. R. Hedke (Report of Committee on Irrigation, 1930) proposed an effective heat method in which the use of water by crops is estimated from a study of the available heat expressed in degree days. The base temperature for determining degree days depends upon the minimum growing temperature for various crops. Hedke proposed the use of the formula

$$
\mathrm{U}=\mathrm{K} \mathrm{H}
$$

where $\mathrm{H}$ is the available heat expressed in degree days and $\mathrm{K}$ is an empirical coefficient. Considerable judgment is required in the selection of $K$, since only limited data are available. A value of about 0.0004 was determined for the Mesilla Valley in New Mexico.

Broader studies by Lowry and Johnson (1942) indicated a linear relation between consumptive use and accumulated daily maximum temperature above $32^{\circ} \mathrm{F}$ during the growing season. Their formula is

$$
\mathrm{U}=0.00015 \mathrm{H}+0.9
$$


in which $\mathrm{U}$ is consumptive use, and $\mathrm{H}$ is the accumulated degree days during the growing season computed from the maximum temperature above $32^{\circ} \mathrm{F}$. Tomlinson (1953) believes that the Blaney and Criddle equation better fits his data for use of water by native hay in Wyoming than does the one suggested by Lowry and Johnson.

Blaney, et al. (1952) developed a formula based on mean monthly temperature and monthly percentage of daytime hours of the year. Expressed mathematically

$$
\mathrm{U}=\mathrm{K} \mathrm{F}=\mathrm{\Sigma} \mathrm{kf}
$$

in which $U$ is the consumptive use of water in inches by the crop for any period; $\mathrm{F}$ is the sum of the monthly consumptive-use factors for the period (sum of the products of mean monthly temperatures, and monthly percentage of daytime hours of the year); and $\mathrm{K}$ is the empirical consumptive-use coefficient.

The monthly consumptive-use factor (f) is equal to (txp)/100 where $t$ is the mean monthly temperature in degrees Fahrenheit; and $\mathrm{p}$ is monthly per cent of daytime hours of the year, taken from the latitudes of the location for which the estimation is being made.

The consumptive-use coefficients $\mathrm{K}$ for the most frequently irrigated crops-grown under normal conditions in the West-(Blaney, 1951; Blaney and Morin, 1942 ; Blaney and Criddle, 1949, 1950 ; Blaney and Ewing, 1949 ; Criddle, 1953) are as follows:

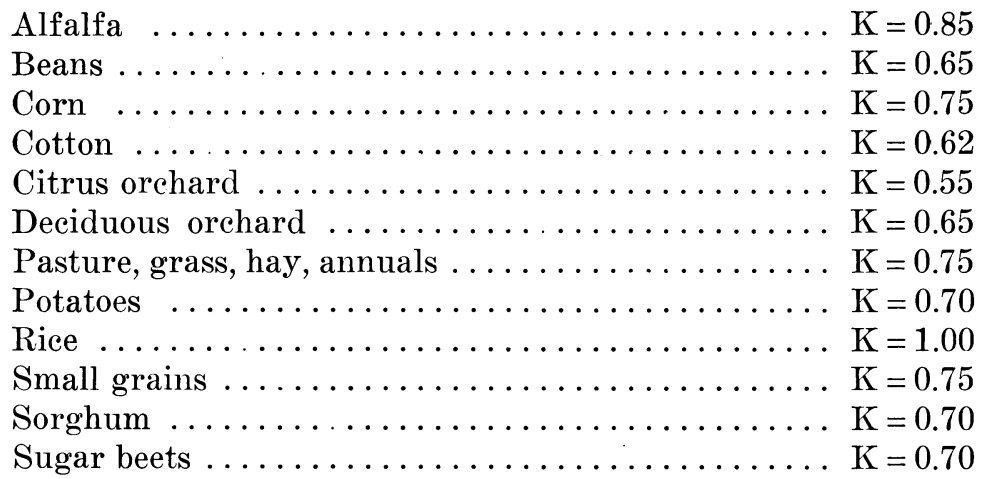

Another empirical formula, developed by Thornthwaite and his associates (Thornthwaite, et al., 1944; Thornthwaite, 1946, 1948; Mather, 1950) is based on latitude and mean temperature, the same elements used by Blaney and Criddle. He believes that the relation between mean monthly temperature and potential evapotranspiration adjusted to a month of 30 days and 12 hours of sunlight per day might be expressed reasonably well by the relation $\mathrm{e}=\mathrm{ct}^{\mathrm{a}}$, where $e$ is the monthly evapotranspiration in centimeters and $t$ is the mean monthly temperature and evapotranspiration has the form

$$
\mathrm{e}=1.6(10 \mathrm{t} / \mathrm{I})^{\mathrm{a}}
$$

where $I$ is the summation of 12 monthly values of the heat index $i$, and

$$
\mathrm{i}=(\mathrm{t} / 5)^{1.514}
$$


The relation between a and $\mathrm{I}$ is closely approximated by the expression

$$
\mathrm{a}=0.000000675 \mathrm{I}^{3}-0.0000771 \mathrm{I}^{2}+0.01792+0.49239
$$

The use of the formula is difficult and without the aid of tables and nomograms, it would be quite unworkable. Space does not permit the inclusion of the tables and nomograms. Those who are interested in this method are referred to other sources in which the matter is treated in detail. Mortensen and Hawthorn (1934) used evaporation records to estimate irrigation requirements. Recently Baver (1954) reviewed some of the methods based on climatic data for determining water requirements for crops.

Penman (1945, 1948, 1952) suggested an equation to calculate the rate of evaporation from wind velocity and vapor pressure. He emphasized the effect of energy changes on evaporation. He uses solar radiation and wind data as criteria for determining use of water by crops. Penman believes the evaporation from a free water surface approximates that from the soil or from certain types of vegetation. His final equation for rate of evaporation is

$$
\mathrm{E}_{\mathrm{o}}=\left(\Delta \mathrm{H}+0.27 \mathrm{E}_{\mathrm{a}}\right) /(\Delta+0.27) \mathrm{mm} / \text { day }
$$

where $\mathrm{E}_{\mathrm{a}}$ is the evaporation when the saturation vapor pressure is that at air temperature. $\mathrm{H}$ is the total amount of energy available for evaporation and heating of the air in $\mathrm{mm}$ per day, and $\Delta$ is the slope of the evaporationtemperature curve when $\mathrm{T}$ is at air temperature. Mean air temperature, mean air vapor pressure, mean wind velocity, and mean duration of sunshine are required to solve the equation. Penman in effect believes that if evaporation from open water, $\mathrm{E}_{\mathrm{o}}$, is known, then transpiration can be calculated by using ratios of transpiration to evaporation, which he has worked out for a given crop, in this instance, turf. There was a seasonal variation in this ratio.

Schofield and Penman (1948) and Schofield (1950) believe that the kind of plant does not materially influence water use. They concluded that evaporation depends more on acreage than on the integrated leaf area because of the close relationship between evaporation and the amount of solar radiation incident upon the vegetated area.

Correlation of Water Use by Crops with Atmometry Records. For many years at the University of California at Davis, changes in soil moisture conditions under different crops have been recorded. These were obtained by sampling the soil where conditions were propitious for such studies. These records serve as satisfactory bases for calculating water losses from the soil in the field where crops are growing. Correlations of certain climatic factors with water use were made by using the formulas suggested by Blaney and Criddle, Lowry and Johnson, and Thornthwaite. The results were not entirely satisfactory. The magnitude of some of the differences between real and calculated values will be pointed out later.

Any method which is based upon the incoming energy to an area will give some correlation with climatic factors and use of water by evaporation and transpiration, but the percentage of error should be small if the calculated results are to be used with confidence.

We believe that the differences in evaporation from standardized black and white surfaces which maintain their characteristics during the growing 
season would be satisfactory instruments to integrate the climatic conditions affecting evaporation and transpiration.

Measurement of Evaporation by Atmometers. The Livingston spherical atmometers (Livingston, 1935; Wilson, 1939, 1940) offered the best possibilities for this use. Dr. B. E. Livingston was the leader in the study and development of atmometry. He suggested that spherical white atmometers made of porous porcelain could be used to measure evaporation. Because they reflected more than 90 per cent of the solar energy falling upon them-and similar black atmometers absorbed more than 90 per cent of the solar energy-the difference in evaporation between the black and white atmometers should be an index of the intensity of radiation. Our studies confirm this conclusion.

Livingston uses the word "atmometer" for "any instrument of whatever form, for measuring or estimating different intensities of evaporativity, which is frequently called evaporation."

How Atmometers Are Used. Figure 3 shows a typical setup of the black and white atmometers for field studies. The equipment is simple and inexpensive. The hollow-porous porcelain spheres are 5 centimeters in diameter with walls about $3-\mathrm{mm}$ thick. When in operation, its moist spherical surface, without any superficial film of water, gives constant and uniform exposure in all directions, excepting below, where the narrow cylindrical neck connects with the supply tube. To care for the slight variations in the size of these spheres each reading is multiplied by a standardization coefficient marked on each sphere used. ${ }^{\circ}$

When an atmometer is soiled by dust or is otherwise contaminated, its coefficient usually increases_although it sometimes decreases. Re-standardization then becomes necessary. Only distilled water should be used in the atmometers; otherwise the pores in the porcelain may become clogged with salt and the sphere will be useless.

The length of the supply tube does not affect the rate of evaporation from the sphere. It may be very short or very long, whichever is convenient for use of the atmometers. The amount of energy required to lift the water from the reservoir to the sphere is so small, compared with the energy required for the latent heat of vaporization, that it does not affect the rate of evaporation.

The porous sphere must always be at a higher level than that of the water in the reservoir so that the hydrostatic pressure in the sphere shall always be somewhat less than the pressure of the atmosphere on the water surface in the reservoir.

The atmometer will absorb rain which falls on it, unless some form of valve is used to prevent absorption. The one most commonly used is that described by Livingston and Thorne (1920). It consists of two porous plugs of compressed sheep's wool or glass wool, almost $2 \mathrm{~cm}$ apart in the supply tube with about 0.3 ec of mercury between the two plugs.

All porous porcelain atmometers are likely to be put out of commission by freezing (Livingston and Haasis, 1929).

${ }^{\circ}$ The atmometers used in these experiments were manufactured by Mrs. B. E. Livingston, 7208 Sherwood Avenue, Riderwood, Baltimore, Maryland, who also supplied the coefficients. These were determined by calibration against atmometers which have been kept for standards for many years. 


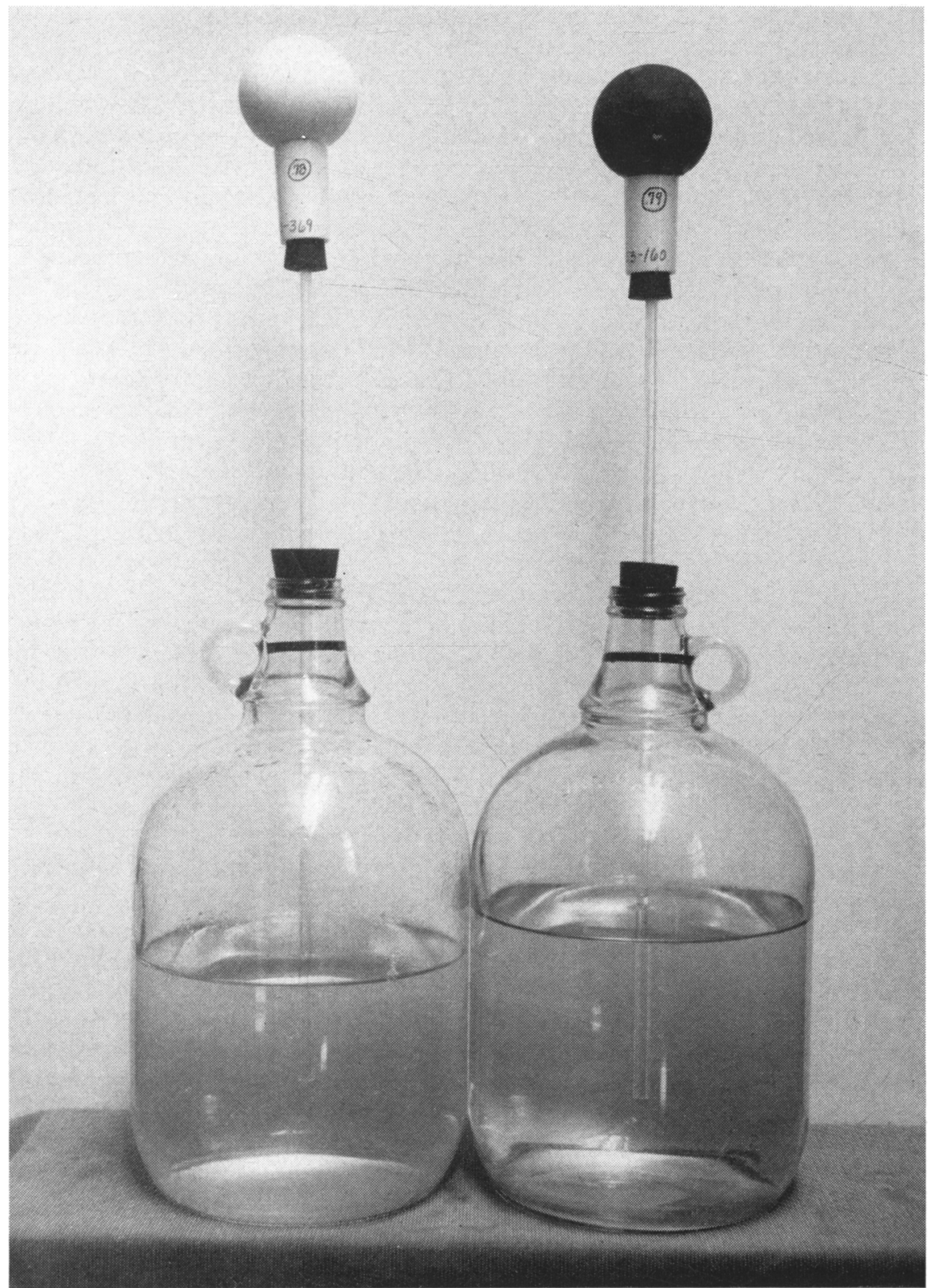

Fig. 3. A set of black and white Livingston spherical, porous porcelain atmometers used at a field station. The evaporation is measured by refilling the jars to the mark on the neck with distilled water from a burette. The measurement mark is thickened here so that it is made visible; actually it is only a thin scrateh. 
Livingston and Wilson (1946) have shown a close relation between vapor pressure deficit and evaporation from a white atmometer.

Wilson and Welton (1935) suggested the use of a standardized Livingston black spherical atmometer as an evaporation index-meter in determining the watering of lawn grasses. Wilson $(1939,1940)$ and Wilson and Savage (1936) have used atmometers to measure evaporation.

Hargreaves (1952) believes that the Piche evaporimeter (Piche, 1873) records correlate well with use of water. There is considerable question whether under very high evaporating conditions this instrument will maintain a constant evaporation surface. It consists of a circular piece of filter paper to which the water is supplied to its center. The diameter of the paper disk is limited by the rate at which water can move outward laterally through the paper. If the edge of the disk tends to become dry in a period of rapid evaporation the disk is, of course, too large (Livingston, 1935).

The long periods in which records of white and black atmometer readings and other climatic data were kept at Davis, together with measurements on use of water by crops, provided an excellent opportunity to determine the correlations between them. As mentioned earlier, there may be correlation between use of water and any measurement which is based upon the incident energy. We believe, however, the correlation between evaporation from a free water surface and use is not good, as will be discussed later. The difference in evaporation from black and white atmometers, on the other hand, and use of water by crops showed very high correlation. The poor agreement between evaporation from a free water surface and use of water by crops probably is due to the fact that transpiration is almost nil during the dark hours while evaporation may be substantial. But the difference between black and white atmometers also is zero during the dark period, as are the readings for the incoming energy measured by an Eppley pyrheliometer. This may explain why the black and white atmometer difference and the pyrheliometer readings and use of water agree.

Table 1 gives the mean monthly use of water by crops and mean monthly differences between black and white atmometers at Davis, Santa Cruz, and Winters. Figure 4 shows the mean cumulative use of water in a peach orchard at Davis for the period 1931-1938 and the mean cumulative differences between black and white atmometers for that period. The cumulative evaporation from a free water surface as measured with a Class A, United States Weather Bureau pan is also shown. Use of water values calculated from the three equations, Blaney and Criddle ; Lowry and Johnson ; and Thornthwaite, are plotted for comparison.

The correlation between mean cumulative use in this peach orchard and mean cumulative differences between black and white atmometers for the entire growing season for the eight-year period, 1931-1938, are shown on figure 5. The changes in slope of the regression lines in the first part of the record are due to the fact that the trees did not come into full leaf until about May 1. The change in slope in the latter part of the record is due to the dropping of the leaves from the trees. These changes may then be attributed to difference in the coverage of the ground by the foliage of the trees in the spring and in the fall. We, therefore, have made our correlations for the 
TABLE 1

MEAN MONTHLY USE OF WATER BY CROPS AND MEAN MONTHLY DIFFERENCE IN EVAPORATION BETWEEN BLACK AND WHITE ATMOMETERS AT DAVIS, WINTERS, AND SANTA CRUZ, CALIFORNIA

\begin{tabular}{|c|c|c|c|c|c|}
\hline Crops and month & $\begin{array}{l}\text { Use of } \\
\text { water }\end{array}$ & $\begin{array}{c}\text { Difference } \\
\text { between } \\
\text { atm. }\end{array}$ & Crops and month & $\begin{array}{l}\text { Use of } \\
\text { water }\end{array}$ & $\begin{array}{l}\text { Difference } \\
\text { between } \\
\text { atm. }\end{array}$ \\
\hline Prunes (1934-38) & inches & $c c$ & Grapes (1933-35) & inches & $c c$ \\
\hline May........... & 5.8 & 547 & May............ & 4.6 & 535 \\
\hline June..................... & 6.0 & 571 & June.................... & 4.9 & 576 \\
\hline July...................... & 7.6 & 700 & July................... & 6.2 & 759 \\
\hline August....................... & 6.5 & 592 & August......... & 5.3 & 614 \\
\hline September................ & 5.0 & 468 & September.............. & 4.3 & 547 \\
\hline Sugar beets (1933-35) & & & Cotton (1947) & & \\
\hline May.............. & 5.2 & 535 & Мay.................... & $\cdots$ & $\ldots$ \\
\hline June.............. & 5.7 & 576 & June..................... & 6.9 & 720 \\
\hline July $\ldots \ldots \ldots \ldots \ldots \ldots \ldots$ & 7.1 & 759 & July................. & 7.4 & 714 \\
\hline 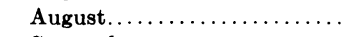 & 5.8 & 614 & August. .................. & 6.0 & 582 \\
\hline September................ & $\ldots$ & $\ldots$ & September............... & 5.0 & 485 \\
\hline Alfalfa (1937-38) & & & Peaches (1931-38) & & \\
\hline 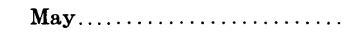 & 6.8 & 532 & May...$\ldots \ldots$ & 5.4 & 530 \\
\hline 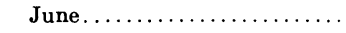 & 7.9 & 597 & June........... & 6.4 & 578 \\
\hline July..................... & 8.3 & 609 & July............. & 7.9 & 691 \\
\hline August.............. & 7.1 & 526 & August................... & 7.2 & 645 \\
\hline September................ & 4.3 & 320 & September............... & 5.0 & 547 \\
\hline Apricots, Winters (1954) & & & Tomatoes (1933-35) & & \\
\hline May $\ldots \ldots \ldots \ldots \ldots$ & $\ldots$ & $\ldots$ & May............ & $\ldots$ & $\ldots$ \\
\hline June............... & 5.6 & 510 & June.................... & 3.2 & $390^{*}$ \\
\hline July............... & 6.8 & 550 & July . ................. & 6.2 & 759 \\
\hline 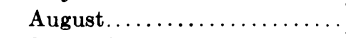 & 6.5 & 520 & August................. & 4.9 & 614 \\
\hline September................. & 4.9 & 400 & September................ & 4.7 & 547 \\
\hline Walnuts (1935-38) & & & Arthichokes, Santa Cruz (1939) & & \\
\hline 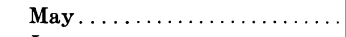 & 6.4 & 493 & 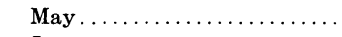 & 3.2 & 440 \\
\hline June..................... & 6.7 & 530 & June..................... & 3.2 & 433 \\
\hline July..................... & 8.4 & 569 & July .................... & 2.8 & 374 \\
\hline 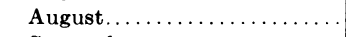 & 7.2 & 533 & August.................. & 2.3 & 325 \\
\hline September......... & 4.8 & 402 & September............... & 2.2 & 318 \\
\hline
\end{tabular}

* This value is for the period June 12 to June 30.

period May 1 to September 30, except for tomatoes and artichokes, which have a shorter period when maximum ground coverage is attained.

Derived Use of Water Coefficients. Figure 6 shows the correlations for the 10 crops studied and indicates the very high degree of correlation between mean monthly use of water and mean monthly difference in evaporation between black and white atmometers. The regression lines were fitted by the method of least squares. An equation expressing this relation may be written as

$$
\mathrm{U}=\mathrm{S} \mathrm{D}
$$

where $\mathrm{U}$ is the use of water by the crop in inches, $\mathrm{S}$ is the slope of the regression line, or it may be called the coefficient, and D is the difference in evaporation between black and white atmometers in cubic centimeters. Table 2 gives the coefficients which may be used to calculate use of water by the different crops and the difference in evaporation between the black and white 


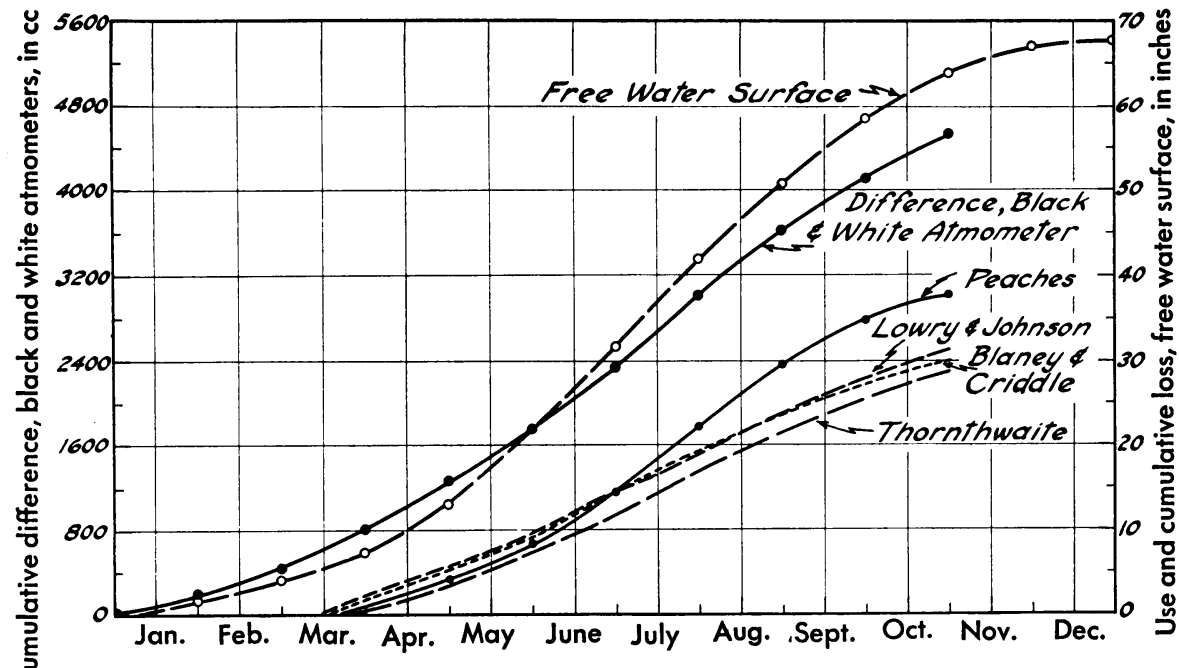

Fig. 4. The mean cumulative use of water in a peach orchard for the period 1931-1938; the mean cumulative difference in evaporation from black and white atmometers; the mean cumulative evaporation from a free water surface; and a Class A, U. S. Weather Bureau pan. The use of water calculated from the Blaney-Criddle, Lowry-Johnson, and Thornthwaite equations are plotted for comparison.

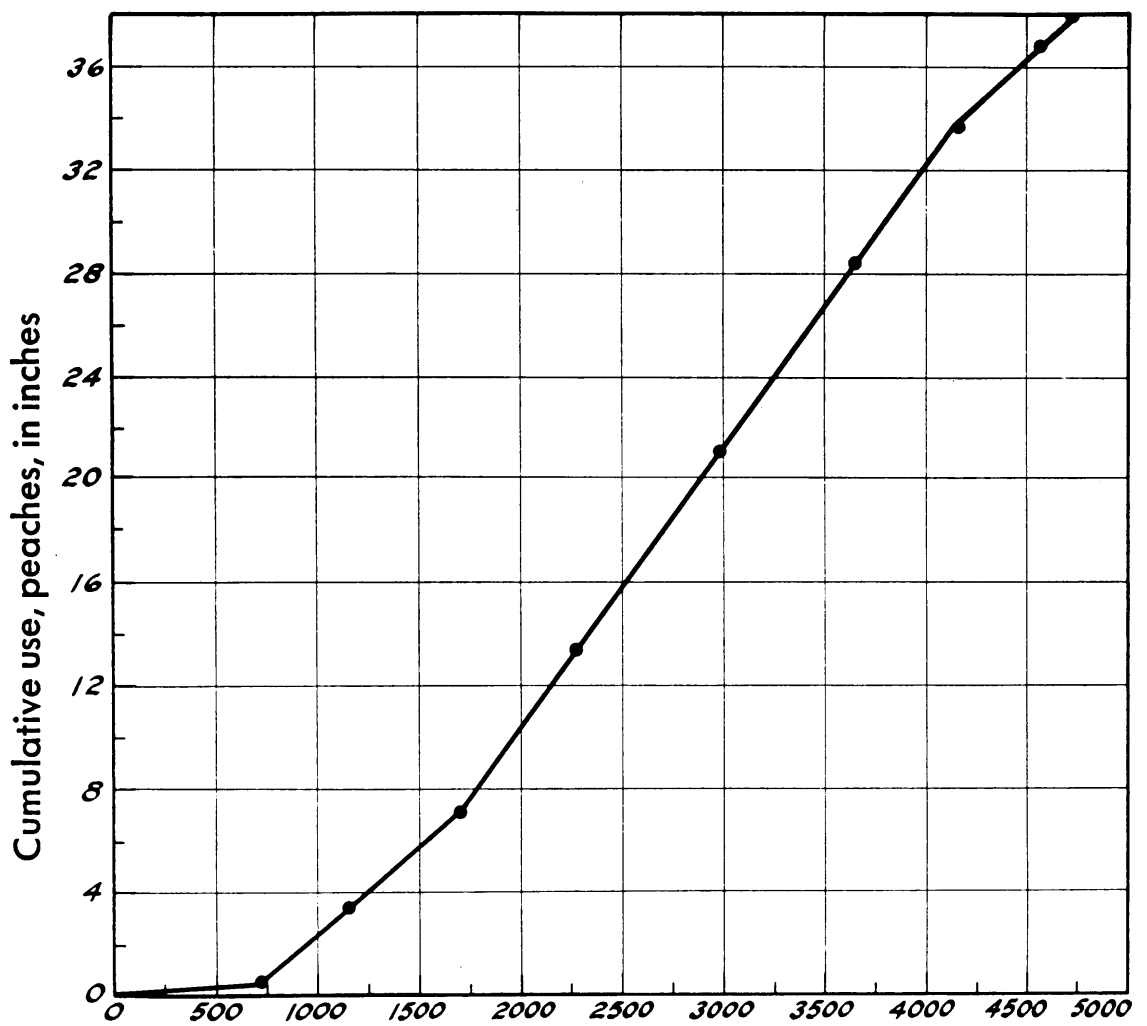

\section{Cumulative difference, black and white atmometers, in cc}

Fig. 5. Cumulative use of water in a peach orchard at Davis and the cumulative difference in evaporation from black and white atmometers, mean values for the period 19311938 . 


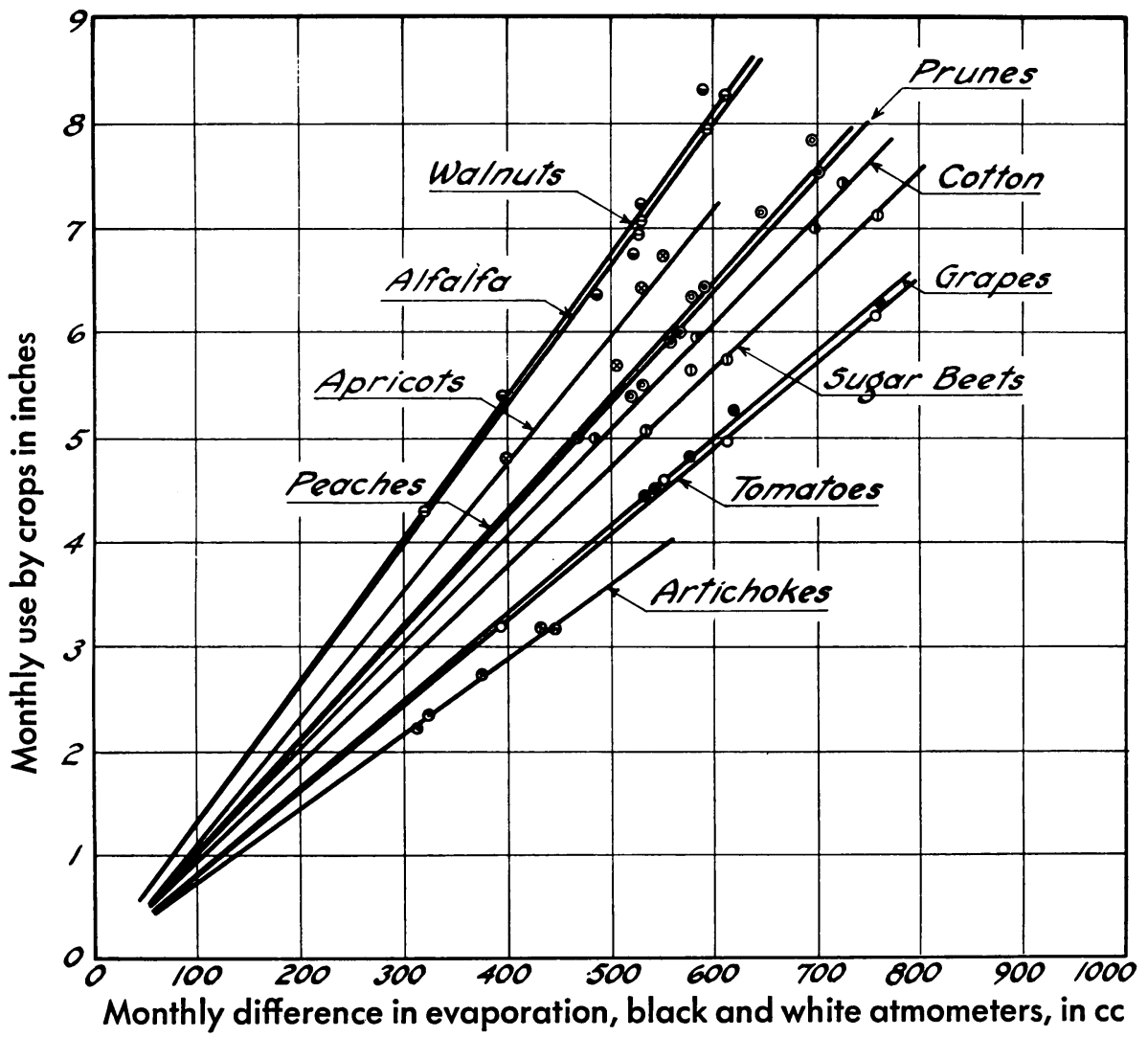

Fig. 6. Mean monthly use of water by crops and mean monthly difference in evaporation between black and white atmometers.

TABLE 2

COEFFICIENTS IN THE FORMULA U = SD, AND THE

CORRELATION COEFFICIENTS FOR WATER USE BY

VARIOUS CROPS AND DIFFERENCE IN EVAPORATION FOR BLACK AND WHITE ATMOMETERS

\begin{tabular}{|c|c|c|}
\hline Kind of crop & $\begin{array}{c}\text { Coefficient } \\
\text { S }\end{array}$ & $\begin{array}{c}\text { Correlation } \\
\text { coefficient* } \\
\text { r }\end{array}$ \\
\hline Alfalfa............... & 0.0134 & 0.99 \\
\hline 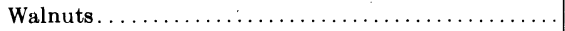 & 0.0135 & 0.97 \\
\hline Apricots $\ldots \ldots \ldots \ldots \ldots \ldots \ldots \ldots \ldots \ldots \ldots$ & 0.0120 & $0.95 \dagger$ \\
\hline Peaches.............. & 0.0110 & 0.98 \\
\hline 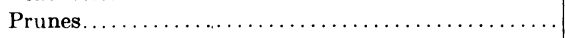 & 0.0108 & 0.98 \\
\hline Cotton .................... & 0.0105 & $0.97 \dagger$ \\
\hline 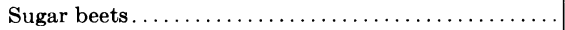 & 0.0096 & 0.99 \\
\hline 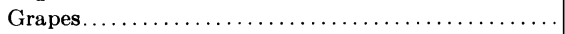 & 0.0086 & 0.98 \\
\hline 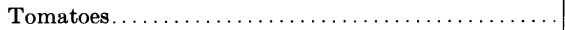 & 0.0082 & 0.98 \\
\hline Artichokes............ & 0.0073 & $0.98 \dagger$ \\
\hline
\end{tabular}

* The correlation coefficients were determined from the formula derived for small samples.

$t$ Values are from one year's record only. For the years of record for which the mean values are calculated for the other crops see table 1. 
atmometers. The average coefficient or correlation is 0.98 which, with the degrees of freedom, gives a correlation of 1 per cent level of significance.

The mean monthly use and the difference between black and white atmometers for sugar beets for the period 1933-1935 are given in figure 7 . The maximum and minimum values obtained during this period are plotted, and

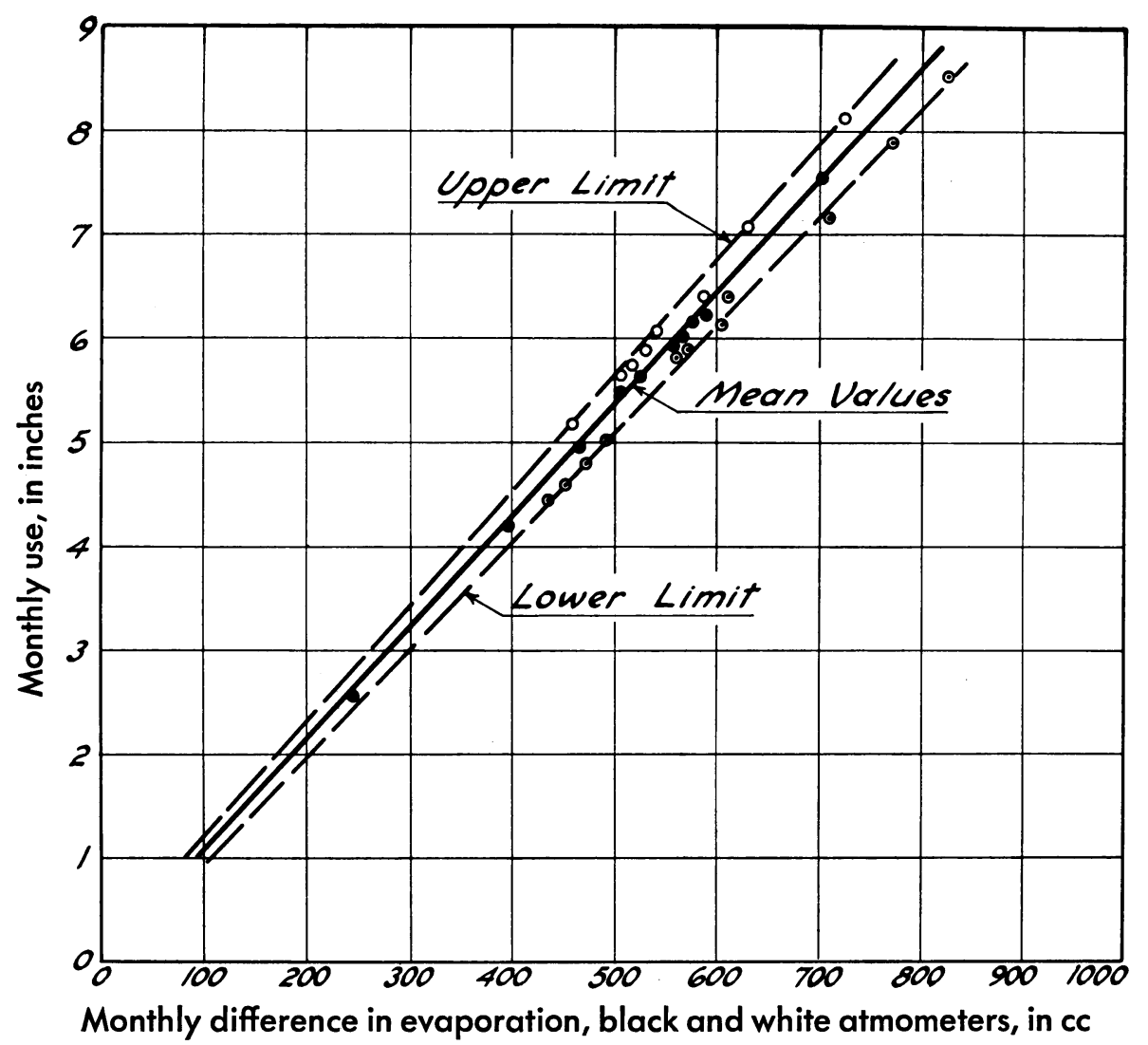

Fig. 7. Mean monthly use of water by a sugar beet crop at Davis, for the period 19331935 , and the mean monthly difference in evaporation between black and white atmometers. The upper and lower limits of the values obtained are indicated.

envelope curves are drawn. This shows the maximum variations obtained, which are less than \pm 5 per cent. Data for prunes from 1934 to 1938 are given in figure 8. Similar records were obtained for the other crops studied.

There were large differences in use of water by the crops for certain months in different years. For instance, in July; 1934, at Davis, the difference in evaporation between black and white atmometers was $1,220 \mathrm{cc}$, while in the same month in 1935 it was only 517 cc. The relation, however, between the black and white atmometer evaporation and use of water which was obtained for the mean monthly use for the entire period over which the data were averaged still held for these months. 
Measured and Calculated Water Use. Table 3 gives the mean use for sugar beets, prunes, tomatoes, and alfalfa as measured by soil moisture studies at Davis. The same table shows values determined according to three widely used methods, as well as the per cent difference between measured and calculated values. Table 3 also includes the corresponding values for the atmometer method.

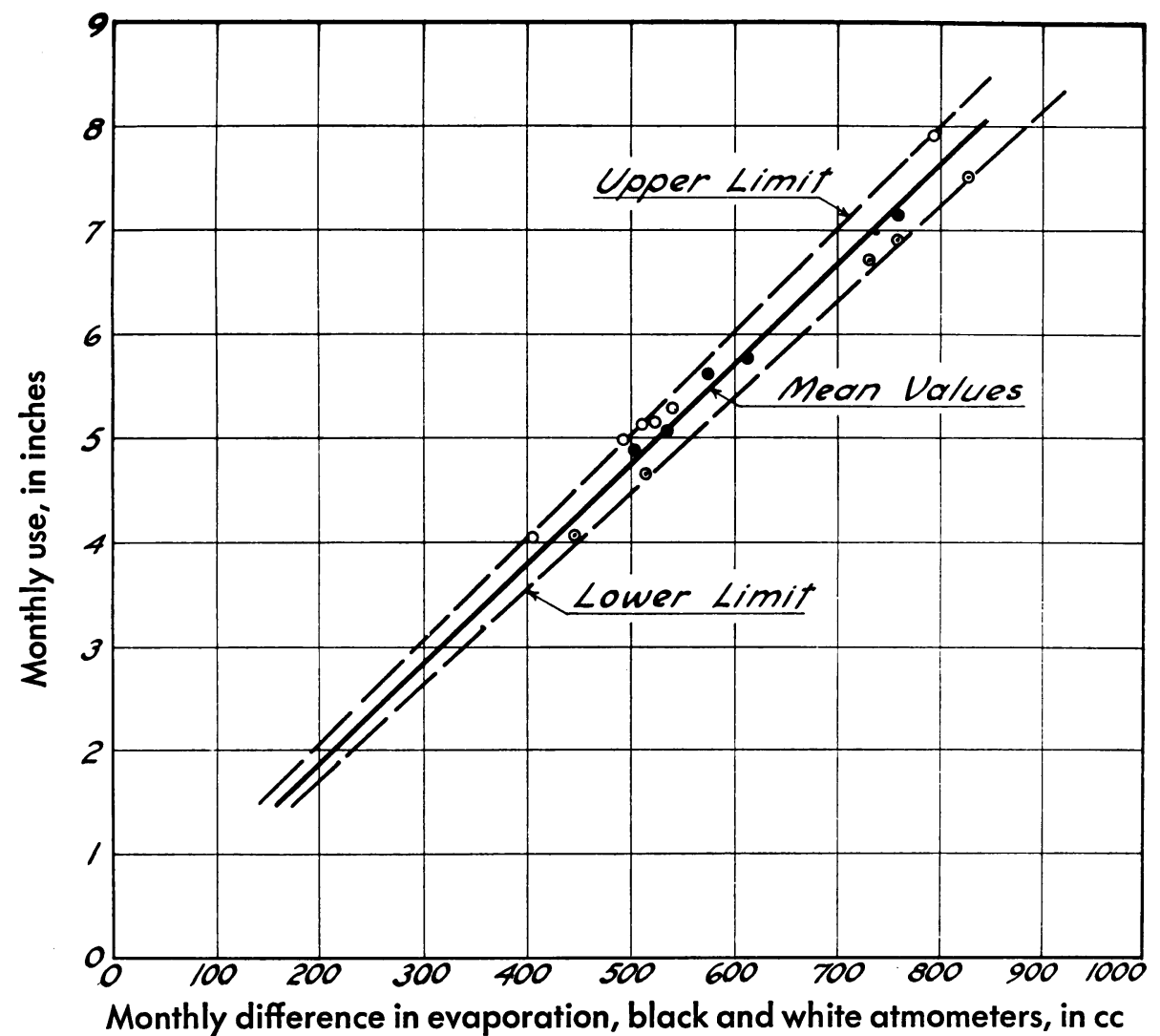

Fig. 8. Mean monthly use of water in a prune orchard at Davis for the period 19341938 , and the mean monthly difference in evaporation from black and white atmometers. The upper and lower limits of the values obtained are indicated.

The most critical month of the growing season for consumptive use of the crops listed in table 1 is July. The range for the four crops, between measured and determined values for July, is as follows:

\section{4-38 per cent for Blaney and Criddle's formula ${ }^{7}$ 11-39 per cent for Lowry and Johnson's formula 9-32 per cent for Thornthwaite's formula and 0.2-8.5 per cent for atmometer method}

\footnotetext{
: The consumptive use coefficient for the entire growing season was used in these calculations, and the computed use rates for the May to September period are therefore somewhat low. The use rates given in table 3 should be calculated from the monthly coefficients, but such data are not available for most of the erops.
} 
TABLE 3

MEAN WATER USE BY CROPS IN INCHES PER MONTH AS MEASURED BY SOIL MOISTURE SAMPLING, AND AS CALCULATED BY FOUR METHODS, AT DAVIS

\begin{tabular}{|c|c|c|c|c|c|c|c|c|c|}
\hline \multirow[b]{2}{*}{ Crop and month } & \multirow{2}{*}{$\begin{array}{c}\text { As } \\
\text { meas- } \\
\text { ured } \\
\text { by soil } \\
\text { moisture } \\
\text { sampling }\end{array}$} & \multicolumn{8}{|c|}{ As determined by four methods } \\
\hline & & $\begin{array}{c}\text { Blaney } \\
\text { and } \\
\text { Criddle* }\end{array}$ & $\begin{array}{c}\text { Per cent } \\
\text { differ- } \\
\text { ence }\end{array}$ & $\begin{array}{c}\text { Lowry } \\
\text { and } \\
\text { Johnson }\end{array}$ & $\begin{array}{c}\text { Per cent } \\
\text { differ- } \\
\text { ence }\end{array}$ & $\begin{array}{l}\text { Thorn- } \\
\text { thwaite }\end{array}$ & $\begin{array}{c}\text { Per cent } \\
\text { differ- } \\
\text { ence }\end{array}$ & $\begin{array}{l}\text { Atmom- } \\
\text { eters }\end{array}$ & $\begin{array}{c}\text { Per cent } \\
\text { differ- } \\
\text { ence }\end{array}$ \\
\hline 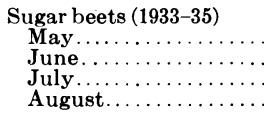 & $\begin{array}{l}5.2 \\
5.7 \\
7.1 \\
5.8\end{array}$ & $\begin{array}{l}4.4 \\
4.9 \\
5.3 \\
4.9\end{array}$ & $\begin{array}{l}15 \\
13 \\
24 \\
14\end{array}$ & $\begin{array}{l}4.1 \\
4.9 \\
5.5 \\
5.5\end{array}$ & $\begin{array}{r}21 \\
14 \\
22 \\
4\end{array}$ & $\begin{array}{l}3.2 \\
4.6 \\
5.7 \\
5.2\end{array}$ & $\begin{array}{l}37 \\
18 \\
19 \\
10\end{array}$ & $\begin{array}{l}5.1 \\
5.5 \\
7.3 \\
5.9\end{array}$ & $\begin{array}{l}0.4 \\
2.9 \\
2.8 \\
2.2\end{array}$ \\
\hline Total. . & 23.8 & 19.5 & 16 & 20.1 & 15 & 18.7 & 21 & 23.8 & 0.6 \\
\hline 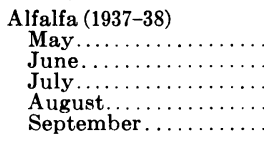 & $\begin{array}{l}6.8 \\
7.9 \\
8.3 \\
7.1 \\
4.3\end{array}$ & $\begin{array}{l}5.5 \\
6.0 \\
6.5 \\
5.9 \\
5.0\end{array}$ & $\begin{array}{l}19 \\
24 \\
21 \\
17 \\
16\end{array}$ & $\begin{array}{l}4.3 \\
4.6 \\
5.2 \\
5.2 \\
4.7\end{array}$ & $\begin{array}{r}38 \\
42 \\
38 \\
27 \\
8\end{array}$ & $\begin{array}{l}4.1 \\
4.8 \\
5.7 \\
4.9 \\
3.9\end{array}$ & $\begin{array}{l}40 \\
39 \\
31 \\
30 \\
10\end{array}$ & $\begin{array}{l}7.1 \\
8.0 \\
8.2 \\
7.1 \\
4.3\end{array}$ & $\begin{array}{l}4.0 \\
1.0 \\
1.4 \\
0.4 \\
0.6\end{array}$ \\
\hline Total........... & 34.4 & 28.9 & 16 & 24.0 & 31 & 23.4 & 32 & 34.7 & 0.5 \\
\hline 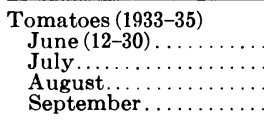 & $\begin{array}{l}3.2 \\
6.2 \\
4.9 \\
4.7 \\
\end{array}$ & $\begin{array}{l}3.0 \\
5.3 \\
5.0 \\
4.1 \\
\end{array}$ & $\begin{array}{r}9 \\
14 \\
1 \\
13\end{array}$ & $\begin{array}{l}2.9 \\
5.5 \\
5.5 \\
4.8 \\
\end{array}$ & $\begin{array}{r}9 \\
11 \\
12 \\
2 \\
\end{array}$ & $\begin{array}{l}2.8 \\
5.7 \\
5.2 \\
3.7 \\
\end{array}$ & $\begin{array}{r}14 \\
9 \\
6 \\
21\end{array}$ & $\begin{array}{l}3.2 \\
6.2 \\
5.0 \\
4.5 \\
\end{array}$ & $\begin{array}{l}1.2 \\
0.2 \\
2.2 \\
3.8 \\
\end{array}$ \\
\hline Total......... & 19.0 & 17.4 & 9 & 18.7 & 2 & 17.4 & 9 & 18.9 & 0.7 \\
\hline 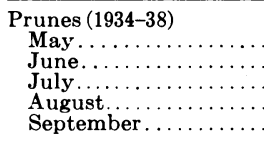 & $\begin{array}{l}5.8 \\
6.0 \\
7.6 \\
6.5 \\
5.0\end{array}$ & $\begin{array}{l}4.5 \\
5.0 \\
5.3 \\
4.9 \\
4.1\end{array}$ & $\begin{array}{l}23 \\
17 \\
30 \\
24 \\
18\end{array}$ & $\begin{array}{l}4.6 \\
5.3 \\
5.9 \\
5.8 \\
5.4\end{array}$ & $\begin{array}{r}22 \\
12 \\
22 \\
11 \\
7\end{array}$ & $\begin{array}{l}3.6 \\
4.7 \\
5.8 \\
5.1 \\
3.9\end{array}$ & $\begin{array}{l}38 \\
21 \\
24 \\
21 \\
22\end{array}$ & $\begin{array}{l}6.0 \\
6.2 \\
7.5 \\
6.4 \\
5.1\end{array}$ & $\begin{array}{l}4.0 \\
2.8 \\
0.2 \\
1.2 \\
0.1\end{array}$ \\
\hline Total........ & 30.9 & 23.8 & 23 & 27.0 & 13 & 23.1 & 25 & 31.2 & 1.6 \\
\hline 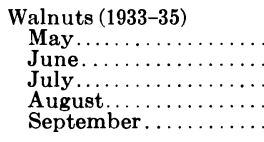 & $\begin{array}{l}6.6 \\
6.7 \\
8.4 \\
7.2 \\
4.8 \\
\end{array}$ & $\begin{array}{l}4.5 \\
5.0 \\
5.3 \\
4.9 \\
4.1 \\
\end{array}$ & $\begin{array}{l}32 \\
26 \\
37 \\
32 \\
14 \\
\end{array}$ & $\begin{array}{l}4.2 \\
4.8 \\
5.1 \\
5.3 \\
4.9 \\
\end{array}$ & $\begin{array}{r}36 \\
29 \\
39 \\
27 \\
3 \\
\end{array}$ & $\begin{array}{l}3.7 \\
4.8 \\
5.7 \\
5.2 \\
3.9 \\
\end{array}$ & $\begin{array}{l}44 \\
28 \\
32 \\
28 \\
19\end{array}$ & $\begin{array}{l}6.7 \\
7.2 \\
7.7 \\
7.2 \\
5.4 \\
\end{array}$ & $\begin{array}{l}1.8 \\
6.4 \\
8.5 \\
0.0 \\
7.5\end{array}$ \\
\hline Total............ & 33.7 & 23.8 & 29 & 24.3 & 28 & 23.3 & 31 & 34.2 & 1.3 \\
\hline 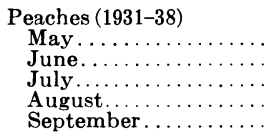 & $\begin{array}{l}5.4 \\
6.4 \\
7.9 \\
7.2 \\
5.0\end{array}$ & $\begin{array}{l}4.2 \\
4.6 \\
5.0 \\
4.6 \\
3.8\end{array}$ & $\begin{array}{l}22 \\
28 \\
36 \\
36 \\
24\end{array}$ & $\begin{array}{l}4.1 \\
4.6 \\
4.8 \\
4.7 \\
4.6\end{array}$ & $\begin{array}{r}24 \\
28 \\
39 \\
35 \\
9\end{array}$ & $\begin{array}{l}3.6 \\
4.7 \\
5.8 \\
5.2 \\
3.8\end{array}$ & $\begin{array}{l}32 \\
26 \\
26 \\
34 \\
24\end{array}$ & $\begin{array}{l}5.8 \\
6.4 \\
7.6 \\
7.1 \\
5.0\end{array}$ & $\begin{array}{l}8.0 \\
0.0 \\
4.0 \\
1.4 \\
0.2\end{array}$ \\
\hline Total... & 31.9 & 22.2 & 30 & 22.8 & 29 & 23.1 & 27 & 31.9 & 0.0 \\
\hline $\begin{array}{c}\text { Cotton (1947) } \\
\text { June................... } \\
\text { July ........ } \\
\text { August..... } \\
\text { September.. }\end{array}$ & $\begin{array}{l}7.0 \\
7.4 \\
6.0 \\
5.0\end{array}$ & $\begin{array}{l}4.4 \\
4.6 \\
4.2 \\
3.8\end{array}$ & $\begin{array}{l}36 \\
38 \\
29 \\
24\end{array}$ & $\begin{array}{l}5.5 \\
6.1 \\
6.0 \\
6.1\end{array}$ & $\begin{array}{r}20 \\
18 \\
0 \\
18\end{array}$ & $\begin{array}{l}4.8 \\
5.9 \\
4.6 \\
4.3\end{array}$ & $\begin{array}{l}31 \\
21 \\
24 \\
15\end{array}$ & $\begin{array}{l}7.6 \\
7.5 \\
6.1 \\
5.1\end{array}$ & $\begin{array}{l}8.7 \\
0.8 \\
1.7 \\
1.0\end{array}$ \\
\hline Total... & 25.4 & 17.0 & 33 & 23.7 & 7 & 19.6 & 23 & 26.3 & 3.2 \\
\hline
\end{tabular}

* In the Blaney and Criddle equation coefficients of 0.70 for sugar beets, tomatoes, prunes, and walnuts; 0.65 for peaches; 0.62 for cotton; and 0.85 for alfalfa were used.

The departures of the calculated values from the true ones for the different months also are given. It is clear that for the total seasonal use or for monthly values, the black and white atmometer method gives the best results.

Atmometry and Use of Water by Graphs. Unfortunately, experimental data of water use and atmometer records are not available for many places. 
However, some were available in Coachella Valley for Thompson Seedless grapes for part of the year 1932. Coachella Valley is quite different climatically from Davis. It is an exceedingly dry, hot area.

Table 4 gives the loss of water in the top 6 feet of soil, as measured by soil moisture sampling, together with the use as determined by atmometers for the months for which a complete record of atmometer readings was available. In these calculations the coefficient of 0.0086 found for muscat grapes at Davis was used. The evaporation from atmometers in ce at Coachella was

TABLE 4

USE OF WATER, IN INCHES, FOR THOMPSON SEEDLESS GRAPES IN COACHELLA VALLEY, CALIFORNIA (1932)

\begin{tabular}{|c|c|c|c|}
\hline Month & $\begin{array}{l}\text { Loss of water } \\
\text { from top six } \\
\text { feet of soil }\end{array}$ & $\begin{array}{c}\text { Determined } \\
\text { by } \\
\text { atmometers }\end{array}$ & $\begin{array}{c}\text { Per cent } \\
\text { difference }\end{array}$ \\
\hline May........... & 4.2 & 4.3 & 2.4 \\
\hline June.... & 6.0 & 5.6 & 7.5 \\
\hline July ...... & 5.5 & 5.4 & 1.8 \\
\hline August.... & 4.1 & 3.9 & 3.9 \\
\hline September. & 3.1 & 3.2 & 4.2 \\
\hline
\end{tabular}

* As measured by soil moisture studies.

TABLE 5

USE OF WATER, IN INCHES, FOR THOMPSON SEEDLESS GRAPES AT SHAFTER, CALIFORNIA (1947)

\begin{tabular}{|c|c|c|c|}
\hline Month & $\begin{array}{l}\text { Loss of water } \\
\text { from } \\
\text { top six feet* }\end{array}$ & $\begin{array}{c}\text { Determined } \\
\text { by atmometers } \\
\text { at Davis }\end{array}$ & $\begin{array}{l}\text { Per cent } \\
\text { difference }\end{array}$ \\
\hline $\operatorname{May} \ldots \ldots \ldots \ldots \ldots \ldots \ldots \ldots \ldots \ldots \ldots \ldots \ldots \ldots$ & 5.8 & 5.4 & 5.6 \\
\hline June $\ldots \ldots \ldots \ldots \ldots \ldots \ldots \ldots \ldots \ldots \ldots \ldots \ldots \ldots$ & 6.2 & 6.2 & 0.8 \\
\hline July .......... & 6.7 & 6.1 & 8.6 \\
\hline 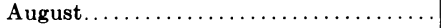 & 5.5 & 5.1 & 7.6 \\
\hline
\end{tabular}

* As measured by soil moisture studies.

converted to use in inches by the use of the coefficient obtained from similar experiments with grapes at Davis.

Table 4 shows that the application of the coefficient derived under climatic and soil conditions different from those at Coachella gave an average percentage of accuracy of about 95 per cent.

Table 5 gives the loss of water in the top 6 feet of soil for grapes at Shafter, in 1947, as measured by soil moisture studies, together with the use calculated from the black and white atmometer record at Davis for the same year. The calculations were made by using the coefficient 0.0086 , table 2 , found for grapes at Davis, because atmometer data were not available from Shafter for 1947.

Table 5 also shows that the average measured use at Shafter was 6 per cent greater than that determined from atmometer readings at Davis. The measured consumptive use for July and August was 8 per cent greater than that determined from atmometers at Davis. 
We assume that the above difference is due to the probable greater insolation occurring at Shafter than at Davis. The receipt of solar energy at Fresno, the station for which pyrheliometer records are available nearest Shafter, averages 1,670 Btu per day. That at Davis is 1,633 Btu.

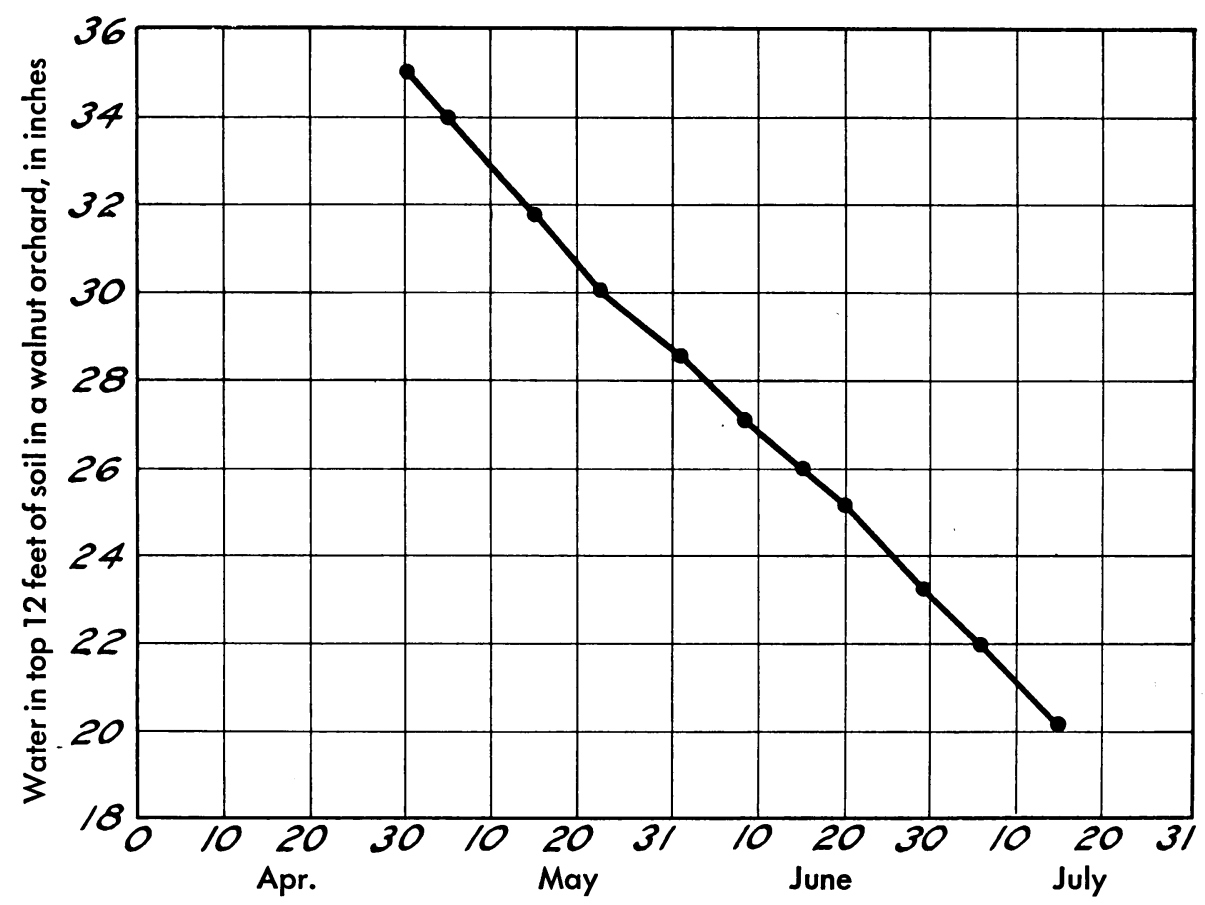

Fig. 9. Soil moisture extraction from the top 12 feet of soil in a walnut orchard at Davis for the period May 1 to July 15. On the latter date the average soil moisture content was reduced to the permanent wilting percentage but the top foot was dried before that date.

Soil Moisture Records. A walnut orchard at Davis, in which the interval of irrigation was not long enough to allow the depletion of the soil moisture, serves to illustrate the constancy of the relation of water use and the difference in evaporation from a black and white atmometer. Figure 9 is the record of soil moisture changes in the top 12 feet of soil during the period of May 1 to July 15. Although the top foot of soil reached the permanent wilting percentage before July 15, there was enough moist soil below this depth to maintain transpiration. The cumulative use of water in inches an 1 the cumulative difference in black and white atmometers' evaporation when plotted against each other are shown in figure 10. The linear relationship for these two values holds throughout the entire range of soil moisture from field capacity to permanent wilting percentage.

These records also show clearly that soil moisture is equally available for transpiration so long as it is above the permanent wilting percentage. If this were not true, soil moisture certainly would become a limiting factor at the low moisture levels and the relationship would not remain linear for the upper part of the curve in figure 10. The departures of the points from the 
straight line doubtless are due to experimental errors. If the last two points in figure 10, which are for the period July 6 to July 15, during which the soil moisture was at the lowest level, were connected by a straight line it would have a slope greater than that of the average line drawn on the chart. This would mean that there was greater rate of use of water during this time than formerly under equal evaporation conditions.

Correlation Data on Evaporation. Data were available to make a cor-

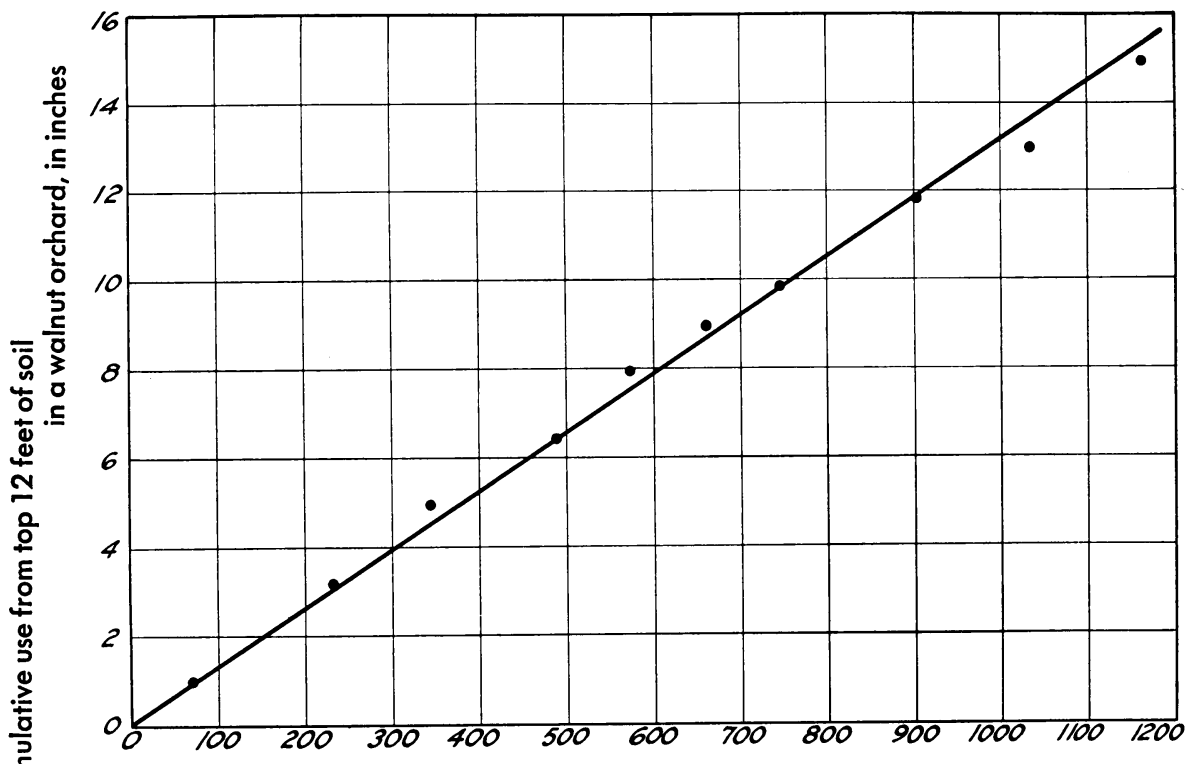

Cumulative difference in evaporation between black and white atmometers, in cc

Fig. 10. Cumulative use of water in a walnut orchard at Davis, and cumulative difference in evaporation between black and white atmometers for the same period shown in figure 9 .

\section{TABLE 6}

MONTHLY EVAPORATION FROM A FREE WATER SURFACE, CLASS A, U. S. WEATHER BUREAU PAN, AND FROM A WHITE ATMOMETER FOR THE PERIOD 1931-1938, AT DAVIS

\begin{tabular}{|c|c|c|c|c|}
\hline Month & $\begin{array}{l}\text { Measured } \\
\text { evaporation } \\
\text { from } \\
\text { free water } \\
\text { surface }\end{array}$ & $\begin{array}{l}\text { Evaporation } \\
\text { from white } \\
\text { atmometer }\end{array}$ & $\begin{array}{c}\text { Calculated* } \\
\text { value for } \\
\text { evaporation } \\
\text { from free water } \\
\text { surface }\end{array}$ & $\begin{array}{c}\text { Difference } \\
\text { between } \\
\text { real and } \\
\text { calculated } \\
\text { values }\end{array}$ \\
\hline & inches & $c c$ & inches & per cent \\
\hline March.. & 3.88 & 762 & 3.87 & 0.2 \\
\hline April ........... & 5.95 & 1,107 & 5.65 & 5.0 \\
\hline May........... & 8.49 & 1,661 & 8.47 & 0.2 \\
\hline June............ & 9.49 & 1,767 & 9.01 & 5.0 \\
\hline July.............. & 11.40 & 2,201 & 11.23 & 1.5 \\
\hline August $\ldots \ldots \ldots \ldots \ldots \ldots \ldots \ldots \ldots$ & 10.29 & 1,945 & 9.92 & 3.7 \\
\hline September $\ldots \ldots \ldots \ldots \ldots \ldots \ldots \ldots \ldots \ldots$ & 7.84 & 1,612 & 8.22 & 4.9 \\
\hline October $\ldots \ldots \ldots \ldots \ldots \ldots \ldots \ldots \ldots \ldots \ldots \ldots \ldots$ & 5.03 & 1,030 & 5.25 & 4.2 \\
\hline
\end{tabular}

* Calculated from the relation, evaporation from free water surface, inches $=0.0051$ evaporation from white atmometer, cc. 
relation of evaporation from a free water surface, Class A, United States Weather Bureau pan, 4 feet in diameter and 10 inches deep, and that from a white atmometer. The data are tabulated in table 6 ; the correlation is shown in figure 11. The line fitted by the method of least squares gives the equation:

Evaporation from pan in inches $=0.0051$ evaporation from white atmometer in ce. The coefficient of correlation is $r=0.98$

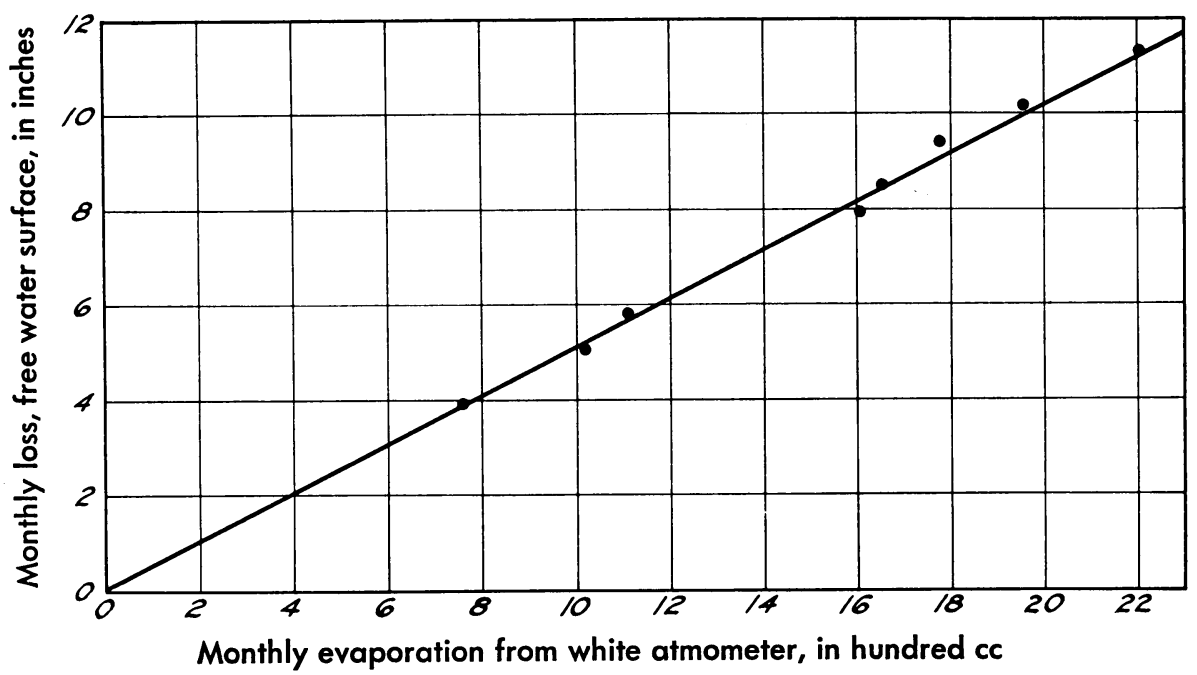

Fig. 11. Relation between mean monthly evaporation from a free water surface, Class A pan, and mean monthly evaporation from a white atmometer, at Davis, 1943-1953. The records are for 7 months, April 1 to October 31 of each year of the 11-year period.

The data show that the spherical white Livingston atmometer can be used to measure the evaporation from a Class A, United States Weather Bureau pan. The simplicity of the atmometer over the pan warrants its use in place of the latter.

The correlation between the monthly use of water by crops and the evaporation from a white atmometer is not good, as can be seen in figure 12. Since the white atmometer evaporation is highly correlated with the evaporation from a free water surface or pan (fig. 11) it follows that the latter's correlation with use also is not good.

Correlation Between Solar Energy and Evaporation. Good correlation between the receipt of solar energy, as measured by an Eppley pyrheliometer at Davis in gram calories per square centimeter, and the difference in evaporation from a black and white atmometer in cubic centimeters was obtained. Table 7 gives the data for the period April 1 to October 31, of each year for 1943 to 1953 . Figure 13 shows the line fitted by the method of least squares to the data. The relationship is given by the equation:

Mean monthly difference in evaporation between black and white atmometers, $\mathrm{cc}=0.028$ mean monthly radiation in gram calories per square centimeter

The coefficient of correlation $r=0.94$ 


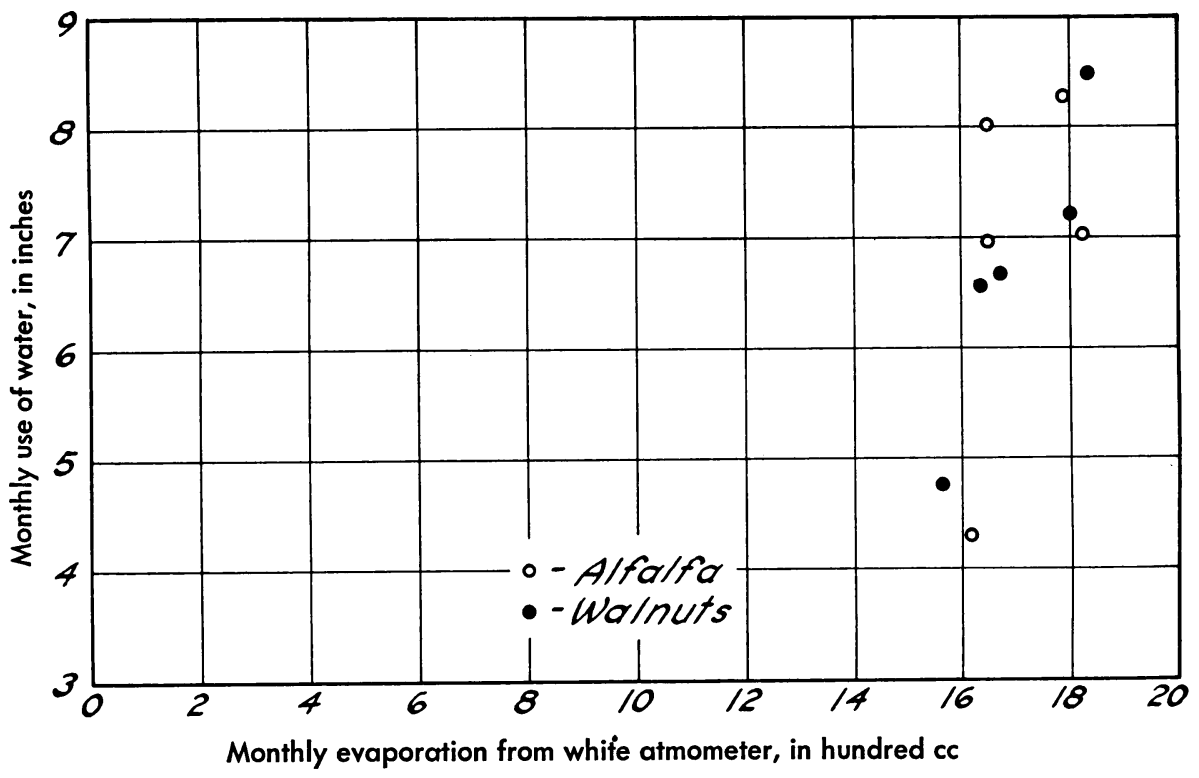

Fig. 12. Mean monthly use of water from a field cropped to alfalfa and from a walnut orchard and mean monthly evaporation from a white atmometer for the period 1935-1938 for walnuts, and 1937-1938 for alfalfa, at Davis.

TABLE 7

RELATIONS BETWEEN TOTAL SOLAR RADIATION* AND DIFFERENCE IN EVAPORATION FROM BLACK AND WHITE ATMOMETERS FOR

THE PERIOD 1943-1953, AT DAVIS

\begin{tabular}{|c|c|c|c|c|c|}
\hline Month & $\begin{array}{l}\text { Mean } \\
\text { monthly } \\
\text { radiation }\end{array}$ & $\begin{array}{c}\text { Difference } \\
\text { in } \\
\text { evaporation } \\
\text { black-white } \\
\text { atmometer }\end{array}$ & Coefficient & $\begin{array}{c}\text { Calculated } \\
\text { value }\end{array}$ & $\begin{array}{l}\text { Difference } \\
\text { between } \\
\text { real and } \\
\text { calculated } \\
\text { values }\end{array}$ \\
\hline & gm.cal. $/ \mathrm{cm}^{2}$ & $c c$ & & $c c$ & per cent \\
\hline April ............... & 15,493 & 400 & 0.028 & 434 & 8.0 \\
\hline May.... & 19,458 & 510 & 0.028 & 545 & 7.0 \\
\hline June..... & 20,665 & 567 & 0.028 & 578 & 1.9 \\
\hline July..... & 21,162 & 619 & 0.028 & 593 & 4.2 \\
\hline August......... & 19,142 & 561 & 0.028 & 536 & 4.5 \\
\hline September $\ldots \ldots \ldots \ldots \ldots \ldots \ldots \ldots \ldots$ & 15,549 & 499 & 0.028 & 435 & 12.8 \\
\hline October $\ldots \ldots \ldots \ldots \ldots \ldots \ldots \ldots \ldots \ldots \ldots \ldots \ldots$ & 11,064 & 333 & 0.028 & 310 & 6.9 \\
\hline
\end{tabular}

* As measured by an Eppley pyrheliometer at Davis. 
This high correlation indicates that pyrheliometer readings may be used with reasonable accuracy to calculate water use by crops. The use of water by crops may be obtained from the readings of solar radiation, which are converted to black and white atmometer values by use of the factor 0.028 .

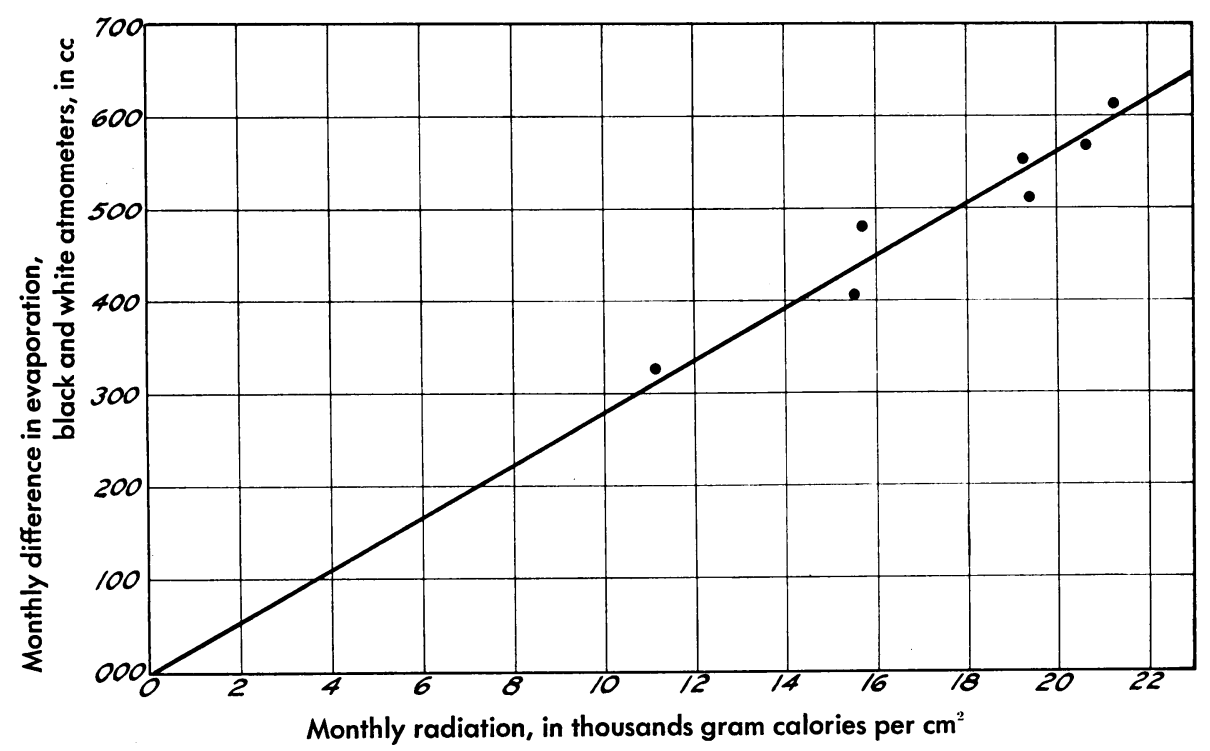

Fig. 13. The relation between the mean monthly difference in evaporation between black and white atmometers and the mean monthly radiation measured by an Eppley pyrheliometer for the period 1943-1953.

\section{DISCUSSION AND SUMMARY}

We believe the best measure of water use by crops is by soil sampling to obtain the changes in soil moisture. The weight per unit volume of dry soil may then be converted to inches use.

Certain conditions must be satisfied for this method to be successful. The crop being studied must have a good, vigorous root system which thoroughly permeates the soil. The soil must be deep enough to accommodate the full rooting depth of the crop, but not so dense that it inhibits penetration of the roots. The soil should be fairly uniform with no sharp changes in texture and structure. The water table must be below reach of the roots.

Best results are obtained with this method if there is a long period without rain during the growing season.

The irrigations should be timed far enough apart so that at least three samplings with appreciable intervals between can be obtained. Enough samples, of course, should be taken to represent the average soil moisture condition in the field.

The permanent wilting percentage of the soil at different depths must be known to determine whether the plants are supplied with available water. It has been shown that the needs of the plant for transpiration and growth will be satisfied if the moisture content of the soil in contact with the absorbing 
portion of the roots is not reduced to the permanent wilting percentage. These conditions were satisfied in our studies on the use of water. Therefore, it has not been necessary to include soil moisture as a variable in our equations.

There is a very good correlation between evaporation from a white spherical Livingston atmometer and evaporation from a free water surface, as measured by a Class A, United States Weather Bureau pan, 4 feet in diameter and 10 inches deep. This suggests that the inexpensive atmometer could be substituted for the pan for measurement of evaporation.

The correlations between evaporation from either a white atmometer or from a free water surface, and use of water by crops are not good. This may be due to the fact that evaporation is affected by wind more than is transpiration and that evaporation continues during the dark period of the day. Transpiration, on the other hand, is almost nil during the night.

The black and white spherical porcelain Livingston atmometers have proved to be excellent instruments for the purpose of estimating the use of water by crops. The difference in evaporation between the black and white atmometers has shown a very high correlation with the use of water by crops.

There is a high correlation between the difference between evaporation from the black and white atmometers in cubic centimeters and the solar radiation, as measured by an Eppley pyrheliometer in gram calories per square centimeter.

The simple atmometer method requires only inexpensive apparatus. The atmometer presents a constant surface to evaporation; in this respect, it is superior to the paper type evaporimeters. The relation between evaporation from a free water surface and that from a white atmometer is:

Evaporation from pan, in inches $=0.0051$ evaporation from white atmometer in ec

The correlation of the difference in evaporation between black and white atmometers and water use by crops holds even though the soil moisture content varies from field capacity to the permanent wilting percentage. That is, transpiration does not decrease as soil moisture decreases. The results, on which this conclusion is based, were obtained from areas of widely different climatic conditions, such as Davis, in the Sacramento Valley ; Santa Cruz, on the coast under relatively low evaporation conditions; Shafter, on the upper end of the interior valley; and Coachella Valley, a very hot, dry area in the south.

The correlation holds throughout the season when the crop has obtained its maximum spread. For deciduous fruit trees this is the period from May 1 to September 30. The relationship is given by the simple equation:

$$
\mathrm{U}=\mathrm{S} \mathrm{D}
$$

where $U$ is the monthly use by the crop in inches, $\mathrm{S}$ is the coefficient or the slope of the regression line, and $\mathrm{D}$ is the difference in monthly evaporation between black and white atmometers in cubic centimeters. The value of $\mathrm{S}$ holds for all locations, but only for the standard surfaces of the Livingston atmometers or their equivalent. It needs, therefore, to be determined only at one place and it can be used to calculate the use of water at any other locality if the data for the black and white atmometers are available. 
The value of $\mathrm{S}$ varies from 0.0073 for artichokes to 0.0135 for walnuts. The coefficients S, for alfalfa and walnuts, are about the same. This suggests that these two crops completely cover the ground and that the total leaf area is relatively unimportant. Also, the height of the plant does not seem to be a determinate factor in water use by crops.

The rate of use of water by crops may vary greatly from year to year. Rates of use by crops varies markedly with different kinds but it seems that if there is equal ground coverage by most crop plants the use is the same in spite of size of individual plants.

There is a high correlation between the evaporation difference between black and white atmometers and the incident energy as measured by an Eppley pyrheliometer. The relation is as follows:

Mean monthly difference in evaporation between the black and white atmometers, in $c c=0.028$ mean monthly radiation in gram calories per square centimeter

The results of these studies justify the use of black and white atmometers to calculate the use of water by crops. If, however, atmometer records are not available the amount of incident energy as measured by the Eppley pyrheliometer may be used for this purpose.

The coefficients derived in this study to calculate the use of water by crops from the difference in evaporation from black and white atmometers apply only to the usual spacing and spread of crops in California.

\section{ACKNOWLEDGMENTS}

We are indebted to Dr. L. D. Doneen for the data on use of water by alfalfa and sugar beets; to Dr. D. W. Henderson for those on cotton; to Professor A. F. Pillsbury for the records for the grape crop in Coachella Valley; and to Mr. A. H. Holland for the soil moisture data for artichokes.

\section{LITERATURE CITED}

BAver, L. D.

1954. The meteorological approach to irrigation control. Hawaiian Planters Record 54:291-98.

BLANEY, H. F.

1951. Consumptive use of water. Amer. Soc. Civ. Engin. Proc. 77 (Separate No. 91):119.

Blaney, H. F., and W. D. Criddle

1949. Consumptive use and irrigation water requirements of crops in Colorado. U. S. Dept. Agr., Div. Irrig. and Water Conservation, Soil Conservation Service. Wash., D.C. 55 pp.

1950. Determining water requirements in irrigated areas from climatological and irrigation data. U. S. Dept. Agr., Div. Irrig. and Water Conservation, Soil Conservation Service, SCS-TP-96, Wash., D.C. 44 pp.

Blaney, H. F., and P. A. Ewing

1949. Irrigation practice and consumptive use of water in Pajaro Valley, California. U. S. Dept. Agr., Div. Irrig. and Water Conservation, Soil Conservation Service. Wash., D.C. December. 62 pp. (Mimeo.)

Blaney, H. F., and K. V. MoRIN

1942. Evaporation and consumptive use of water empirical formulas. Amer. Geophys. Union Trans. Part I:76-83. August. 
Blaney, H. F., L. R. Rich, W. D. Criddle, G. B. Gleason, and R. L. Lowry 1952. Consumptive use of water. Amer. Soc. Civ. Engin. Trans. 117:948-1023.

Bhiggs, L. J., and H. L. Shantz

1916a. Hourly transpiration rate on clear days as determined by cyclic environmental factors. Jour. Agr. Res. 5 (2) :583-649.

1916b. Daily transpiration during the normal growth period and its correlation with weather. Jour. Agr. Res. 7 (4):155-212.

Criddle, W. D.

1953. Consumptive use of water and irrigation requirements. Jour. Soil and Water Cons. 8(5):207-12; 243. September.

Doneen, L. D., and D. W. Henderson

1952. Soil conditions affecting infiltration of water and root development. Amer. Soc. Sugar Beet Tech. Proc. pp. 214-23.

1954. Distribution of the roots in soil of some annual plants. (Personal communication.)

Hargreaves, A. H.

1952. Discussion on consumptive use. Amer. Soc. Civ. Engin. Trans. 117:968-71.

KITTRIDGE, J.

1941. Report of committee on transpiration and evaporation. Amer. Geophys. Union Trans. 22:906-15.

LEWIS, M. R., R. A. Work, and W. W. ALDRICH

1935. Influence of different quantities of moisture in a heavy soil on rate of growth of pears. Plant Physiol. 10:309-13.

Livingston, B. E.

1935. Atmometers of porous porcelain and paper, their use in physiological ecology. Ecology XVI(3):438-72.

Livingston, B. E., and F. HaAsis

1929. The measurement of evaporation in freezing weather. Jour. Ecol. 17:315-28.

Livingston, B. E., and F. THORNE

1920. A simplified non-absorbing mounting for porous atmometers. Science 52:85-87.

Livingston, B. E., and J. D. WiLson

1946. Relation of vapor-pressure deficit to evaporation from a spherical atmometer in an air-conditioned room. Science 104:487-88.

Lowry, R. L., and A. F. JoHnson

1942. Consumptive use of water for agriculture. Amer. Soc. Civ. Engin. Trans. 107: 1243-52.

MATHER, J. R.

1950. Micrometeorology of the surface layer of the atmosphere. Manual of Evapotranspiration. Supplement to Interim Report 10:1-29. The Johns Hopkins Lab. of Climatology, Seabrook, N.J.

Mortensen, E., and L. R. HAWTHoRN

1934. The use of evaporation records in irrigation experiments with truck crops. Amer. Soc. Hort. Sci. Proc. 30:466-69.

Penman, H. L.

1945. The dependence of transpiration on weather and soil conditions. Soil Sci. I:74-89.

1948. Natural evaporation from open water, bare soil and grass. Roy. Soc. Isondon Proc., Series A, 193:120-45.

1952. The physical bases of irrigation control. Thirteenth Internatl. Hort. Congress Report and Proc. II:913-24.

Piche, Albert

1873. "Note sur l' atmometre, instrument destinee a mesurer l'evaporation." Bul. Assoc. Sci. France 10:166-67. Sci. Pour Tous, Paris 17, 226. Ann. Sci. Indust. [Paris] 16:58-60. Zeitschr. Oest. Ges. Met. 8:270-71.

REPORT OF THE DUTY OF W ATER COMMITTEe OF THE IRRIGATION DIVISION

1930. "Consumptive Use of Water in Irrigation." Amer. Soc. Civ. Engin. Trans. 94: 1349-99.

SCHOFIELD, R. K.

1950. Soil moisture and evaporation. Fourth Internatl. Congress Soil Sci. Trans. 2: 20-28. 
Schomeld, R. K., and H. L. Penman

1948. The principles governing transpiration by vegetation. Conf. Biol. and Civ. Engin. Proc. pp. 75-98.

ThoRnthWAITE, C. W.

1946. The moisture-factor in climate. Amer. Geophys. Union Trans. 27:41-48.

1948. An approach toward a rational classification of climate. Geog. Rev. 38:55-94.

THORNTHWAITE, C. W., et al.

1944. Report of the Committee on Evaporation and Transpiration. Amer. Geophys. Union Trans. 25:686-93.

Tombinson, B. R.

1953. Comparison of two methods of estimating consumptive use of water. Agr. Engin. 34:459-64.

VEIHMEYER, F. J.

1927. Some factors affecting the irrigation requirements of deciduous orchards. Hilgardia 2(6): $125-288$.

1938. Evaporation from soils and transpiration. Amer. Geophys. Union Trans. 19:61219.

1953. Use of water by native vegetation versus grasses and forbs on watersheds. Amer. Geophys. Union Trans. 34:201-12.

VEIHMEYER, F. J., and F. A. BRoOKS

1954. Measurement of cumulative evaporation from bare soil. Amer. Geophys. Union Trans. 35:601-07.

VEIHMEYER, F. J., and A. H. HENDRICKSON

1948. Soil density and root penetration. Soil Sci. 65:487-93.

1949. Methods of measuring field capacities and permanent wilting percentages of soils. Soil Sei. 68:75-99.

1950. Soil moisture in relation to plant growth. Plant Physiol. Ann. Rev. 1:265-304.

1955. Does transpiration decrease as the soil moisture decreases? Amer. Geophys. Union Trans. 36:425-28.

Veinmeyer, F. J., and A. H. Holland

1949. Irrigation and cultivation of lettuce. California Agr. Exp. Sta. Bul. 711:1-52.

WILson, J. D.

1939. Evaporation studies III, ten years of evaporation at Wooster as measured with black and white atmometers. Ohio Agr. Exp. Sta. Bi-monthly Bul. 24 (197):11-25.

1940. An evaporation-index meter for use in irrigation practice. Ohio Agr. Exp. Sta. Bi-monthly Bul. 25 (202):3-6.

Wilson, J. D., and J. R. SAvAge

1936. An evaporation survey of Ohio. Ohio Agr. Exp. Sta. Bul. 564:1-53.

WILSON, J. D., and F. A. WELTON

1935. The use of an evaporation-index in watering lawns. Ohio Agr. Exp. Sta. Bimonthly Bul. 20 (174):112-19.

Work, R. A., and M. R. LEWIS

1936. The relation of soil moisture to permanent wilting in a heavy clay soil. Amer. Soc. Agron. Jour. 28:124-34. 

The journal Hilgardia is published at irregular intervals, in volumes of about 600 pages. The number of issues per volume varies.

Subscriptions are not sold. The periodical is sent as published only to libraries, or to institutions in foreign countries having publications to offer in exchange.

You may obtain a single copy of any issue free, as long as the supply lasts; please request by volume and issue number from:
Agricultural Publications
Room 22, Giannini Hall
University of California
Berkeley 4, California

The limit to nonresidents of California is 10 separate issues on a single order. A list of the issues still available will be sent on request.

In our publications it is sometimes convenient to use trade names of products or equipment rather than scientific identifications. In so doing it is unavoidable in some cases that similar products which are on the market under other trade names may not be cited. No endorsement of named products is intended nor is criticism implied of similar products which are not mentioned. 


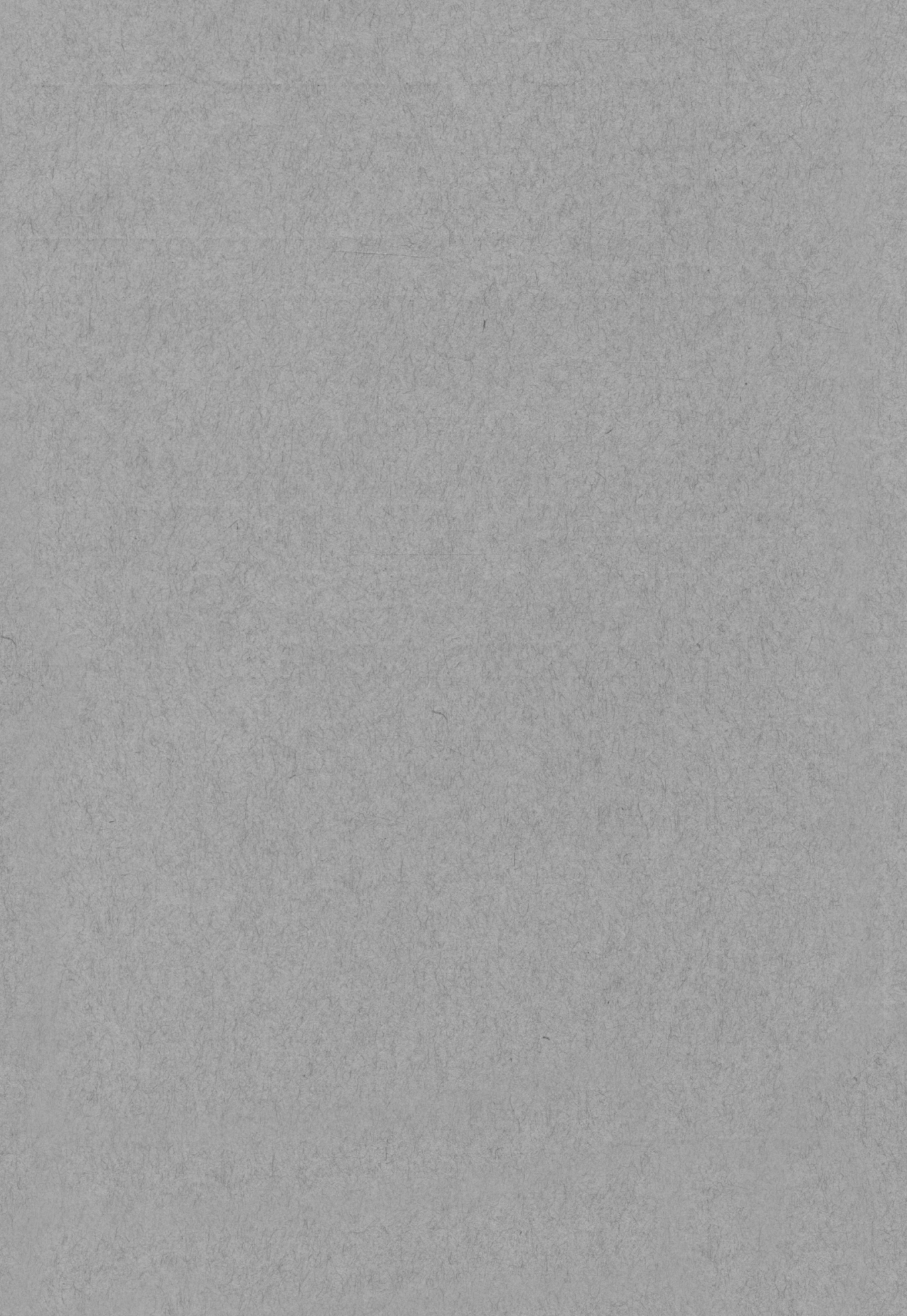

